\title{
Pathology of Neurodegenerative Diseases
}

\author{
Brittany N. Dugger ${ }^{1}$ and Dennis W. Dickson ${ }^{2}$ \\ ${ }^{1}$ Institute for Neurodegenerative Diseases, Department of Neurology, Weill Institute for Neurosciences, \\ University of California, San Francisco, San Francisco, California 94143 \\ ${ }^{2}$ Mayo Clinic, Jacksonville, Florida 32224 \\ Correspondence: brittany.dugger@ucsf.edu
}

\begin{abstract}
Neurodegenerative disorders are characterized by progressive loss of selectively vulnerable populations of neurons, which contrasts with select static neuronal loss because of metabolic or toxic disorders. Neurodegenerative diseases can be classified according to primary clinical features (e.g., dementia, parkinsonism, or motor neuron disease), anatomic distribution of neurodegeneration (e.g., frontotemporal degenerations, extrapyramidal disorders, or spinocerebellar degenerations), or principal molecular abnormality. The most common neurodegenerative disorders are amyloidoses, tauopathies, $\alpha$-synucleinopathies, and TDP-43 proteinopathies. The protein abnormalities in these disorders have abnormal conformational properties. Growing experimental evidence suggests that abnormal protein conformers may spread from cell to cell along anatomically connected pathways, which may in part explain the specific anatomical patterns observed at autopsy. In this review, we detail the human pathology of select neurodegenerative disorders, focusing on their main protein aggregates.
\end{abstract}

$\mathrm{N}_{\mathrm{c}}^{\mathrm{e}}$ urodegenerative disorders can be broadly classified by their clinical presentations, with extrapyramidal and pyramidal movement disorders and cognitive or behavioral disorders being the most common. Few patients have pure syndromes, with most having mixed clinical features. The current diagnostic gold standard is neuropathological evaluation at autopsy (see Table 1 for summary). Although neurodegenerative diseases are typically defined by specific protein accumulations and anatomic vulnerability, neurodegenerative diseases share many fundamental processes associated with progressive neuronal dysfunction and death, such as proteotoxic stress and its attendant abnormalities in ubiquitin-proteasomal and autophagosomal/lysosomal systems, oxidative stress, pro- grammed cell death, and neuroinflammation. Furthermore, it is critical to note that protein abnormalities that define neurodegenerative diseases can be present before the onset of clinical features (Gibb and Lees 1988; Sparks et al. 1994; Schmitt et al. 2000; Adler et al. 2010; Evidente et al. 2011; Frigerio et al. 2011; Milenkovic and Kovacs 2013; Dugger et al. 2014c) and more than one neurodegenerative disease process can be found in an individual (Uchikado et al. 2006a; Dugger et al. 2014a). At present, diagnostic biomarkers are not available, except in rare cases in which a causative genetic mutation can be shown to cause the disorder (Ghasemi and Brown 2016; Gijselinck et al. 2016; Hinz and Geschwind 2016; TCW and Goate 2016). Hence, specific in vivo biomarkers, including biofluid

Editor: Stanley B. Prusiner

Additional Perspectives on Prion Biology available at www.cshperspectives.org

Copyright (C) 2017 Cold Spring Harbor Laboratory Press; all rights reserved; doi: 10.1101/cshperspect.a028035

Cite this article as Cold Spring Harb Perspect Biol 2016;9:a028035 
B.N. Dugger and D.W. Dickson

Table 1. Overview of select neurodegenerative diseases

\begin{tabular}{|c|c|c|c|}
\hline Disease & Main neuropathology & $\begin{array}{c}\text { Protein } \\
\text { aggregate(s) }\end{array}$ & Main anatomic vulnerability \\
\hline $\begin{array}{l}\text { Amyloidoses } \\
\text { Creutzfeldt-Jakob disease } \\
\text { (genetic, variant, sporadic, } \\
\text { iatrogenic) }\end{array}$ & $\begin{array}{l}\text { Spongiform changes } \\
\text { Prion protein }(\mathrm{PrP}) \\
\text { accumulation }\end{array}$ & $\operatorname{PrP}$ & $\begin{array}{l}\text { Cerebral cortex } \\
\text { Neostriatum } \\
\text { Thalamus } \\
\text { Cerebellum }\end{array}$ \\
\hline $\begin{array}{l}\text { Gerstmann-Sträussler- } \\
\text { Scheinker disease }\end{array}$ & $\begin{array}{l}\text { Spongiform change } \\
\text { Multicentric PrP plaques }\end{array}$ & $\operatorname{PrP}$ & $\begin{array}{l}\text { Cerebral cortex } \\
\text { Cerebellum }\end{array}$ \\
\hline Familial British dementia & $\begin{array}{l}\text { Amyloid angiopathy } \\
\text { Parenchymal amyloid } \\
\text { plaques }\end{array}$ & ABRI & $\begin{array}{l}\text { Cerebral cortex } \\
\text { Cerebellum }\end{array}$ \\
\hline Alzheimer's disease & $\begin{array}{l}\text { Neurofibrillary tangles } \\
\text { (NFTs) } \\
\text { Neuropil threads } \\
\text { Neuritic and amyloid } \\
\text { plaques } \\
\text { Amyloid angiopathy }\end{array}$ & $\begin{array}{l}\mathrm{A} \beta \\
3 \mathrm{R}+4 \mathrm{R} \text { tau }\end{array}$ & $\begin{array}{l}\text { Basal forebrain } \\
\text { Frontal and temporal lobes } \\
\text { Limbic structures } \\
\text { Locus coeruleus } \\
\text { Olfactory bulb }\end{array}$ \\
\hline $\begin{array}{l}\text { Tauopathies } \\
\text { Chronic traumatic } \\
\text { encephalopathy }\end{array}$ & $\begin{array}{l}\text { Astrocytic tau tangles } \\
\text { Neuropil threads } \\
\text { NFTs }\end{array}$ & $3 \mathrm{R}+4 \mathrm{R}$ tau & $\begin{array}{l}\text { Frontal, temporal, and parietal } \\
\text { lobes } \\
\text { Depth of sulci and surrounding } \\
\text { vasculature }\end{array}$ \\
\hline Primary age-related tauopathy & NFTs & $3 \mathrm{R}+4 \mathrm{R}$ tau & $\begin{array}{l}\text { Basal forebrain } \\
\text { Brainstem } \\
\text { Medial temporal lobe } \\
\text { Olfactory bulb }\end{array}$ \\
\hline Pick's disease & $\begin{array}{l}\text { Pick bodies } \\
\text { Pick cells/ballooned } \\
\text { neurons }\end{array}$ & $3 \mathrm{R}$ tau & $\begin{array}{l}\text { Basal forebrain } \\
\text { Frontal and temporal lobes } \\
\text { Limbic structures } \\
\text { Striatum }\end{array}$ \\
\hline Progressive supranuclear palsy & $\begin{array}{l}\text { Globose NFTs } \\
\text { Tufted astrocytes } \\
\text { Oligodendroglial coiled } \\
\text { bodies } \\
\text { Neuropil threads }\end{array}$ & $4 \mathrm{R}$ tau & $\begin{array}{l}\text { Subthalamic nucleus } \\
\text { Substantia nigra } \\
\text { Superior colliculus } \\
\text { Cerebellar dentate }\end{array}$ \\
\hline Corticobasal degeneration & $\begin{array}{l}\text { Pretangles } \\
\text { Astrocytic plaques } \\
\text { Neuropil threads } \\
\text { Ballooned neurons }\end{array}$ & $4 \mathrm{R}$ tau & $\begin{array}{l}\text { Frontoparietal association } \\
\text { cortices } \\
\text { Neostriatum } \\
\text { Substantia nigra }\end{array}$ \\
\hline Argyrophilic grain disease & $\begin{array}{l}\text { Argyrophilic grains } \\
\text { Ballooned neurons } \\
\text { Coiled bodies } \\
\text { Ramified astrocytes }\end{array}$ & $4 \mathrm{R}$ tau & Limbic structures \\
\hline $\begin{array}{l}\text { Aging-related tau } \\
\text { astrogliopathy }\end{array}$ & $\begin{array}{l}\text { Thorn-shaped astrocytes } \\
\text { Granular astrocytes }\end{array}$ & $4 \mathrm{R}$ tau & $\begin{array}{l}\text { Subpial and perivascular spaces } \\
\text { Mediobasal forebrain } \\
\text { Amygdala }\end{array}$ \\
\hline
\end{tabular}

Continued 
Table 1. Continued

\begin{tabular}{|c|c|c|c|}
\hline Disease & Main neuropathology & $\begin{array}{c}\text { Protein } \\
\text { aggregate(s) }\end{array}$ & Main anatomic vulnerability \\
\hline \multicolumn{4}{|l|}{ Synucleinopathies } \\
\hline \multirow[t]{7}{*}{ Lewy body disorders } & Lewy bodies & \multirow[t]{7}{*}{$\alpha$-Synuclein } & Amygdala \\
\hline & Lewy neurites & & Cerebral cortex \\
\hline & & & Dorsal motor nucleus \\
\hline & & & Hippocampus (CA2) \\
\hline & & & Locus coeruleus \\
\hline & & & Olfactory bulb \\
\hline & & & Substantia nigra \\
\hline \multirow[t]{6}{*}{ Multiple system atrophy } & Glial cytoplasmic & \multirow[t]{6}{*}{$\alpha$-Synuclein } & Putamen \\
\hline & inclusions & & Substantia nigra \\
\hline & & & Pontine nuclei \\
\hline & & & Medulla (inferior olivary \\
\hline & & & nucleus) \\
\hline & & & Cerebellum \\
\hline \multicolumn{4}{|l|}{ TDP-43 Proteinopathies } \\
\hline \multirow{4}{*}{$\begin{array}{l}\text { Frontotemporal lobar } \\
\text { degeneration }\end{array}$} & Neuronal cytoplasmic & \multirow[t]{4}{*}{ TDP-43 } & Frontal and temporal cortices \\
\hline & inclusions & & Basal ganglia \\
\hline & $\begin{array}{l}\text { Neuronal nuclear } \\
\text { inclusions }\end{array}$ & & Substantia nigra \\
\hline & Dystrophic neurites & & \\
\hline \multirow[t]{6}{*}{ Amyotrophic lateral sclerosis } & Upper and lower motor & \multirow[t]{6}{*}{ TDP-43 } & Motor cortex \\
\hline & neuron loss & & Brainstem motor neurons \\
\hline & Bunina bodies & & Spinal cord motor neurons \\
\hline & Neuronal inclusions & & \\
\hline & Astrocytic hyaline & & \\
\hline & inclusions & & \\
\hline \multirow[t]{2}{*}{ Primary lateral sclerosis } & Upper motor neuron loss & \multirow[t]{2}{*}{ TDP-43 } & Motor cortex \\
\hline & $\begin{array}{l}\text { Corticospinal tract } \\
\text { degeneration }\end{array}$ & & Corticospinal tracts \\
\hline \multirow[t]{2}{*}{ Progressive muscular atrophy } & Lower motor neuron loss & \multirow[t]{2}{*}{ TDP-43 } & Brainstem motor neurons \\
\hline & Swollen motor neurons & & Spinal cord motor neurons \\
\hline
\end{tabular}

and molecular imaging markers (some highlighted in Kolb and Andres 2016; Seeley 2016), are a major research priority.

The most common neurodegenerative disorders are amyloidoses, tauopathies, $\alpha$-synucleinopathies, and transactivation response DNA binding protein 43 (TDP-43) proteinopathies. Abnormal protein conformations in these disorders and their cellular and neuroanatomical distribution constitute the major histopathologic features essential in making a specific neuropathologic diagnosis. Examples of protein accumulations within neurons include tau in neurofibrillary tangles (NFTs) or Pick bodies, $\alpha$-synuclein in Lewy bodies, and TDP-43 in neuronal cytoplasmic and neuronal intranuclear inclusions. Protein accumulations within astrocytes include tau in tufted astrocytes, astrocytic plaques, and thorn-shaped astrocytes. Protein accumulations within oligodendroglia include tau in coiled bodies and $\alpha$-synuclein in glial cytoplasmic inclusions. These abnormal protein aggregates are composed of intrinsic neuronal proteins and other cellular components, in contrast to neuronal inclusions found in viral infections where the protein is foreign. In many cases, the protein has an abnormal conformation with amyloid-like properties. 
B.N. Dugger and D.W. Dickson

Most form filaments, and their secondary structures are enriched in $\beta$-pleated sheets. Amyloid stains, such as Congo red and thioflavin S, can be used to detect many protein aggregates, including amyloid plaques, NFTs, and a subpopulation of Lewy bodies, but other aggregates are better detected with silver-staining methods. Immunohistochemistry is the preferred method for studying neurodegenerative disorders today because of better interlaboratory and inter-rater reliability (Alafuzoff et al. 2009a,b; 2015).

Cross-sectional postmortem evaluations of a large number of human brains from patients with a range of clinical and pathological severity have suggested that many neurodegenerative disorders have a stereotypic progression that can be described by stages. Staging schemes have been developed for Alzheimer's disease (AD) (Braak and Braak 1991; Thal et al. 2002), Parkinson's disease (PD) (Braak et al. 2003), dementia with Lewy bodies (DLB) (Kosaka et al. 1984), amyotrophic lateral sclerosis (ALS) (Brettschneider et al. 2013), frontotemporal lobar degeneration associated with TDP-43 pathology (FTLD-TDP) (Brettschneider et al. 2014), and chronic traumatic encephalopathy (CTE) (McKee et al. 2013). Studies highlighted in this volume (Braak and Del Tredici 2016), combined with evidence of functional connectivity from in vivo imaging as discussed in this volume (Seeley 2016), have ushered in a new way of thinking about selective vulnerability in neurodegenerative disorders.

\section{AMYLOIDOSES}

Amyloids are insoluble fibrous proteins that have specific structural characteristics, including a $\beta$-sheet-rich secondary structure, which permits binding by specific dyes, such as Congo red. The protein abnormalities of almost all common neurodegenerative diseases have some characteristics of amyloid; however, only a subset of these disorders has abundant extracellular protein aggregates, which are the defining feature of non-neural amyloidoses (Westermark et al. 2005). In neurodegenerative diseases, amyloid-like filamentous aggregates are mostly within the cytoplasm of neurons and glia. Extracellular deposits of amyloid can be found in the brain parenchyma as plaques or in the walls of blood vessels as amyloid angiopathy (Fig. 1). Amyloid plaques have a wide range of morphologies and have been further subdivided into diffuse ("primitive") plaques, dense-cored ("burnt-out") plaques, "classical" plaques, and cotton wool plaques (Dickson 1997). The morphologic variation is specific to the type or species of amyloid, stage of disease, and to the neuroanatomical location where the deposit is found. The most common amyloidosis is a proteolytic product of the amyloid precursor protein, which is encoded by a gene on chromosome 21 (Kang et al. 1987), and is referred to as $\beta$ amyloid or $A \beta$. $A \beta$ isolated from human brain is biochemically heterogeneous in terms of size of peptide fragments and posttranslational modifications (Kuo et al. 2001). Although $A \beta$ is a defining feature of $\mathrm{AD}$, amyloid deposits are found as a comorbid feature of many neurodegenerative disorders in the elderly, especially in those individuals carrying the major genetic risk factor for $\mathrm{AD}$, apolipoprotein $\mathrm{E} 4$ (Josephs et al. 2004). Much less common than $A \beta$ disorders are those in which other types of amyloid are deposited, such as prion protein (PrP) in familial and sporadic Creutzfeldt-Jakob disease (CJD) (Goldfarb et al. 1991) and Gerstmann-Sträussler-Scheinker disease (GSS) (Hsiao et al. 1991), and ABri in familial British and Danish dementias (Vidal et al. 1999, 2000).

\section{Prion Diseases}

The key molecular event of prion diseases is the conversion of the normal cellular prion protein, $\mathrm{PrP}^{\mathrm{C}}$, into the pathogenic form, $\mathrm{PrP}^{\mathrm{Sc}}$. The term "prion" was first coined in 1982 by Stanley B. Prusiner as a name for the transmissible agent that caused scrapie in sheep and goats, and appeared to be composed only of protein; it was an amalgamation of the words protein and infection (Prusiner 1982). Because of their transmissibility, prion diseases are classified as infectious diseases. Disorders that have been shown to be caused by PrP include GSS, fatal familial insomnia, kuru, and sporadic (including variant and 

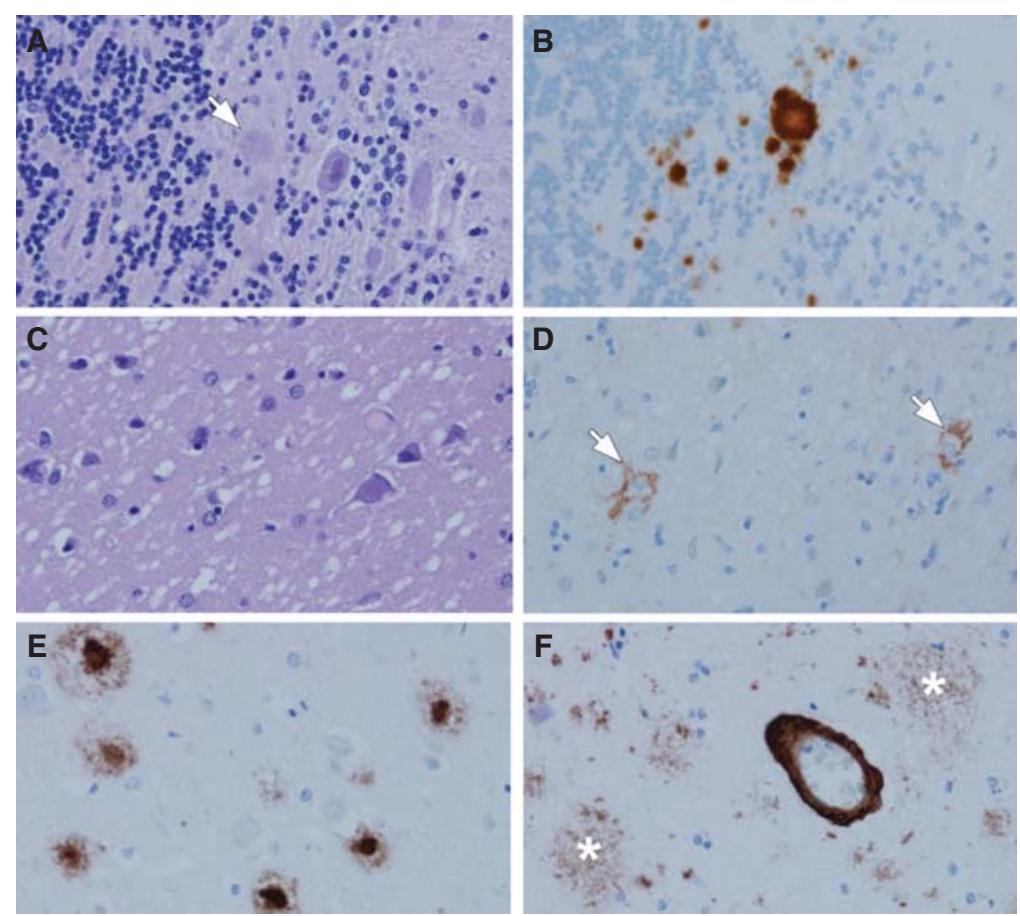

Figure 1. Amyloidoses: Gerstmann-Sträussler-Scheinker disease (GSS) (A,B), Creutzfeldt-Jakob disease (CJD) $(C, D)$, and Alzheimer's disease $(\mathrm{AD})(E, F)$. In GSS, dense-cored amyloid plaques can be detected with hemotoxylin and eosin (H\&E) staining, arrow $(A)$, but immunohistochemistry for human PrP (monoclonal antibody $3 \mathrm{~F} 4$ ) reveals more clearly the multicentric nature of the deposits $(B)$. One of the hallmark histologic features of CJD is the spongiform change in affected cortical and subcortical areas $(C)$ with a perineuronal synaptic pattern of $\mathrm{PrP}$ deposition (arrows) in an adjacent section $(D)$. In $\mathrm{AD}$, amyloid deposits detected with immunohistochemistry (monoclonal antibody 6F/3D) are heterogeneous and include those with dense cores, especially in primary cortices $(E)$, as well as poorly circumscribed and noncompact diffuse plaques in the cortex (asterisks) $(F)$. In addition to parenchymal deposits, most cases of AD also have amyloid angiopathy $(F)$.

familial) and iatrogenic CJD (Ellison 2013). There is considerable clinical and pathologic heterogeneity in these disorders, but they all show an accumulation of pathological $\operatorname{PrP}$ (Fig. 1B,D) that is associated with neuronal and synaptic loss, microvacuolation (spongiform change, Fig. 1C), and gliosis. By definition, they are transmissible to other humans (naturally or iatrogenically) or to experimental animal models and are sometimes referred to as transmissible spongiform encephalopathies. Prion diseases are categorized based on genetics and route of transmission (for review, see Prusiner 1998).

CJD is often a rapidly progressive dementia, and the brain frequently has little if any atrophy. In some cases, there is decreased brain weight and ventricular enlargement and variable atrophy of the thalamus and caudate nucleus. White matter is relatively spared, with the most characteristic pathology occurring in gray matter. Spongiform change (Fig. 1C) and gliosis occur variably in cerebral and cerebellar cortices, with frequent involvement of subcortical structures (e.g., neostriatum). Spongiform change should not be confused with superficial laminar spongiosis, which is common in other neurodegenerative disorders, especially FTLD (Kertesz et al. 1994) or the restricted spongiform pathology that is frequent in limbic structures and the temporal lobe in DLB (Sherzai et al. 2013). Immunohistochemistry for PrP 
B.N. Dugger and D.W. Dickson
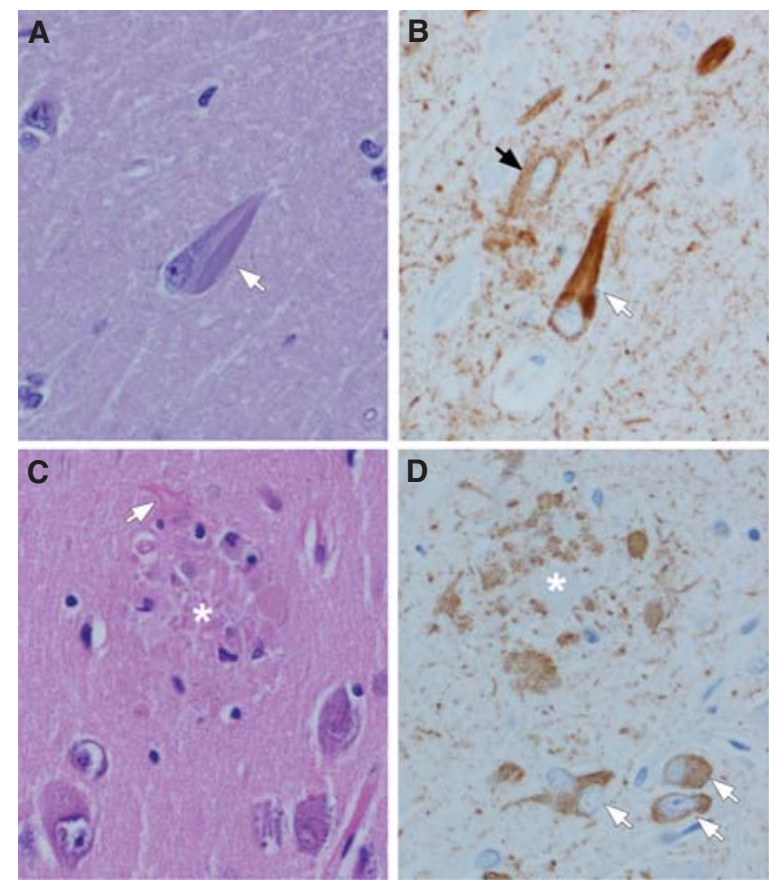

Figure 2. Tau pathology in AD: Neurofibrillary tangles (NFTs) $(A, B)$ and neuritic plaques $(C, D)$. Flame-shaped intracellular NFTs (arrow) can be detected as bundles of basophilic filaments in pyramidal neurons of the hippocampus $(A)$. Immunohistochemistry for phospho-tau shows not only NFTs (white arrow), but also pervasive neuropil threads and a pretangle (black arrow) that are not visible with routine histology. Neuritic plaques (asterisk) can also be detected with routine histology $(C)$ because of central dense amyloid, clusters of swollen cell processes, activated microglia, and surrounding reactive astrocytes (arrow). Immunohistochemistry for phospho-tau shows clusters of irregular, swollen cell processes around a central unstained region $(D)$ (i.e., amyloid core [asterisk]). Note also neuropil threads and several NFTs and pretangles (arrows). (Immunohistochemistry with CP13, whose epitope is near phosphoserine 202.)

shows abnormal deposition in a perineuronal (Fig. 1D) or synaptic pattern as perivacuolar deposits or as dense-cored plaques (Budka et al. 1995).

\section{Alzheimer's Disease}

The neuropathology of $\mathrm{AD}$ is a mixed proteinopathy that includes the presence of both $A \beta$ deposits in the parenchyma as amyloid or senile plaques (Fig. 1E,F), as well as neuronal tau inclusions (i.e., NFTs) (Fig. 2A,B). Most cases also have amyloid angiopathy (Fig. 1F). It is thought that the earliest amyloid plaques are noncompact, diffuse amyloid deposits (Fig. 1F), which have been referred to as "pre-amyloid" deposits (Tagliavini et al. 1988) because of their weak or absent staining with traditional amyloid dyes. Depending on the brain region, amyloid deposits can also have dense cores (Fig. 1E), which frequentlyoccur in the primary motor and visual cortices. Amyloid plaques have heterogeneous cellular components, including neuronal processes ("dystrophic neurites") and both astroglial processes and microglia. Microglia are particularly frequent in association with dense deposits (Fukumoto et al. 1996). The most clinically significant type of plaque in $\mathrm{AD}$ is one in which there are tau-immunoreactive dystrophic neurites ("neuritic plaques") (Fig. 2C,D) (Dickson 1997). Determining the density of neuritic plaques and the topographic distribution of NFTs is required for neuropathological diagnosis of AD (Hyman and Trojanowski 1997), with 
neuritic plaques assessed using a semiquantitative method proposed by the Consortium to Establish a Registry for Alzheimer's Disease (CERAD) (Mirra et al. 1991). The most recent revision of neuropathological criteria (Montine et al.2012) includes an assessment of topographic distribution rather than density of amyloid deposits using a staging scheme proposed by Thal et al. (2002). The five Thal amyloid "phases" take into account the location of $A \beta$ deposits, with phases 1 and 2 having plaques restricted to the neocortex and hippocampus, progressing to the striatum in phase 3 , and to the brainstem and cerebellum in phases 4 and 5, respectively.

\section{TAUOPATHIES}

Disorders associated with pathological accumulation of tau protein in neurons and glia are referred to as tauopathies (Lee et al. 2001; Dickson et al. 2011; Spillantini and Goedert 2013; Kovacs 2015) and further subdivided as either primary or secondary. In secondary tauopathies, a driving force other than tau is considered primary. The best example is $\mathrm{AD}$, but others include familial British dementia (Holton et al. 2001) and GSS (Ghetti et al. 1995). Tau is a microtubule-associated phosphoprotein abundant in axons involved in promoting polymerization and stabilization of microtubules (Binder et al. 1985; Buee et al. 2000; Mandelkow and Mandelkow 2012). In addition to phosphorylation, tau undergoes other posttranslational modifications, such as ubiquitination, nitration, glycation, and acetylation, all of which have been linked to abnormal tau that accumulates in degenerative tauopathies (Morishima and Ihara 1994; Alonso et al. 2008; Martin et al. 2011; Cook et al. 2014). Discovery of mutations in the gene for tau protein, $M A P T$, in frontotemporal dementia and parkinsonism linked to chromosome 17 (FTDP17T) (Hutton et al. 1998) demonstrated that abnormalities in the tau protein could cause neurodegeneration.

Tau protein exists as six major isoforms produced by alternative mRNA splicing of exons 2, 3, and 10 (Andreadis 2005). Alternative splicing of exon 10 generates three isoforms with four conserved $\approx 32$-amino-acid repeats (4R tau), whereas three isoforms have three repeats ( $3 \mathrm{R} \mathrm{tau}$ ) in the domain critical for binding to microtubules. The number and types of these tau isoforms vary in a cell-type and disease-specific manner and even segregate in experimental cell models (Woerman et al. 2016). For example, tau in glial cells is composed predominantly of $4 \mathrm{R}$ tau. The relative amounts of $3 \mathrm{R}$ and $4 \mathrm{R}$ tau that accumulate differ in neurodegenerative tauopathies (for further review, see Buee et al. 2000; Andreadis 2005; Mandelkow and Mandelkow 2012). The 4R tauopathies include progressive supranuclear palsy (PSP), corticobasal degeneration (CBD), argyrophilic grain disease (AGD), and some forms of FTDP17T. The 3R tauopathies include Pick's disease and some forms of FTDP-17T, whereas 3R/4R tauopathies include AD, CTE, tangle predominant dementia, Guam Parkinson dementia complex, and some forms of FTDP-17T (Mackenzie et al. 2010).

\section{Alzheimer's Disease}

$\mathrm{AD}$ is the most prevalent of the tauopathies and is considered a secondary tauopathy because mutations that cause AD in the presenilin genes (PSEN1 and PSEN2) and the amyloid precursor protein gene $(A P P)$ are characterized by initial or primary alterations in amyloid metabolism (Hardy et al. 1998). In contrast, mutations in MAPT produce tauopathies, but to date none produce AD. Macroscopic changes in AD include variable atrophy of multimodal association cortices in the frontal, temporal, and parietal lobes, with a subset of cases also showing occipital lobe atrophy. The degree of cortical atrophy correlates closely with the distribution and density of tau pathology and the clinical syndrome, but not with amyloid plaques (Josephs et al. 2008b; Whitwell et al. 2008).

Microscopically, two lesions define the pathology of $\mathrm{AD}$-amyloid plaques (discussed above) and NFTs (Fig. 2A,B), which are composed predominantly of tau protein (Masters et al. 1985; Grundke-Iqbal et al. 1986). As NFTs mature, the neuron bearing the inclusion dies, leaving an extracellular ("ghost") NFT. Tau 
aggregates are present not only in neuronal perikarya as NFTs, but also in dystrophic neuronal processes (mostly distal axons) in neuritic plaques (Fig. 2C, D) and in neuritic processes that are pervasive throughout affected gray matter. The latter have been termed "neuropil threads" (Braak et al. 1986). Molecular profiling of tau in $\mathrm{AD}$ reveals that there is nearly an equimolar ratio of $3 \mathrm{R}$ and $4 \mathrm{R}$ tau (Goedert et al. 2006), but immunohistochemistry with monoclonal antibodies specific to $3 \mathrm{R}$ and $4 \mathrm{R}$ tau show distinct regional differences. For example, the extracellular tangles in the medial temporal lobe are disproportionately immunoreactive for 3R tau (Espinoza et al. 2008).

NFTs in aging and $\mathrm{AD}$ progress in an anatomically hierarchical fashion, with six stages proposed by Braak and Braak (1991). In the six Braak NFT stages, stage I begins in the transentorhinal cortices, followed by the hippocampus and limbic cortices (stages II-III) and multimodal association cortices (stages IV-V), with the primary cortices the last affected (stage VI). A recent revision of this scheme suggests that tau pathology in subcortical areas, such as the locus coeruleus in the pons, may precede medial temporal lobe pathology (Braak et al. 2011). Although AD has both NFTs and amyloid deposits, some elderly individuals have only NFTs. This process is termed "primary age-related tauopathy" (PART), with most cases having early Braak NFT stages (I-IV) (Crary et al. 2014).

Although most AD cases follow the Braak staging scheme, a subset of AD, as many as $20 \%$, do not fit. These include patients with severe neurofibrillary pathology relatively limited to limbic lobe structures ("limbic predominant AD") and patients in which the hippocampus is relatively spared, whereas higher-order neocortical areas bear the brunt of the neurofibrillary pathology ("hippocampal-sparing AD") (Murray et al. 2011). Limbic predominant AD tends to be a slowly progressive disorder of the elderly with a severe amnestic syndrome, whereas hippocampal-sparing $\mathrm{AD}$ often affects younger individuals and may present with focal cortical syndromes (Murray et al. 2011). Although these variants of $\mathrm{AD}$ differ with respect to distribution of neurofibrillary pathology, no differences have been detected in the distribution of amyloid plaques to date (Janocko et al. 2012).

\section{Chronic Traumatic Encephalopathy}

The sequelae of chronic repetitive head injury have been known for many years as CTE (for review, see Montenigro et al. 2015), but it has also been referred to as "punch drunk syndrome" or "dementia pugilistica," in part because it was originally reported in boxers (Roberts 1988). The clinical syndrome is variable but often associated with behavioral and cognitive features (Stern et al. 2013). It is considered a primary tauopathy, but unlike all other tauopathies, an etiologic environmental factor (i.e., repetitive concussive or subconcussive head injury) has been identified. This condition has drawn increasing attention for its connection to repetitive head injury associated with contact sports, such as American football (McKee et al. 2009).

Depending on the duration of the disease, the brain may appear macroscopically normal or show varying degrees of cerebral atrophy in the frontal and temporal lobes, with ventricular enlargement. Some patients have fenestration of the cavum septum pellucidum. Tau that accumulates in NFTs in CTE is similar to that in $\mathrm{AD}$, namely, 3R/4R tau (Schmidt et al. 2001). The distribution of NFTs differs from AD, with initial neurofibrillary pathology in superficial cortical layers (Hof et al. 1992), often at the depths of sulci and proximal to blood vessels (Fig. $3 \mathrm{~A}, \mathrm{~B})$, with medial temporal lobe involvement at later stages (McKee et al. 2013).

Recent neuropathologic criteria have been proposed for CTE (McKee et al. 2015). The pathognomonic lesion is abnormal hyperphosphorylated tau in neurons and astroglia distributed around small blood vessels at the depths of cortical sulci and in an irregular pattern. A four-tiered staging scheme has been proposed for CTE, with tau pathology initially in discrete foci ("epicenters") in the cerebral cortex (stages I and II), with more widespread cortical and medial temporal lobe involvement in stage III. The last stage 

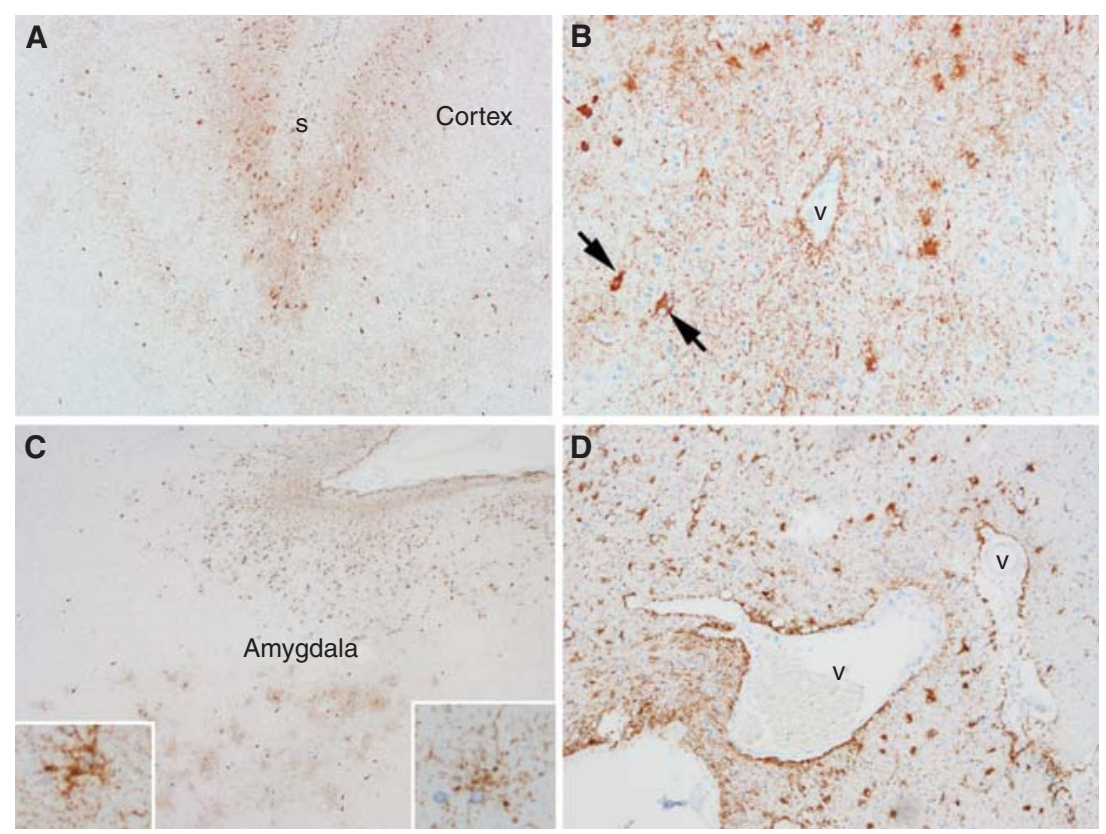

Figure 3. Tau pathology in chronic traumatic encephalopathy (CTE) $(A, B)$ and aging-related tau astrogliopathy (ARTAG) $(C, D)$. The characteristic lesion in CTE is a focal cluster of neuronal and glial tau concentrated at the depths of a sulcus $(s)(A)$, with preferential involvement of superficial cortical layers. Higher magnification shows neuronal (arrows) and astroglial tau preferentially around blood vessels (v) (B). In ARTAG, taupositive astrocytes are concentrated at the pial surface in the transverse fissure at the base of the brain $(C)$. At the pial surface, the astrocytes are thorn-shaped $(C$, left lower inset), whereas the astrocytes in gray matter have granular cytoplasmic processes $(C$, right lower inset). Tau-positive astrocytes are concentrated at the glia limitans around penetrating blood vessels $(\mathrm{v})(D)$. (Immunohistochemistry with CP13, whose epitope is near phosphoserine 202.)

(stage IV) has pathology affecting the cerebral cortex and subcortical structures (McKee et al. 2013). The staging scheme remains to be validated, but preliminary studies suggest that CTE can be detected in nonprofessional athletes in the setting of other neurodegenerative diseases (Bieniek et al. 2015).

Although astroglial tau pathology is clearly a feature of CTE pathology, it is not specific. The defining lesion in CTE is neuronal tau pathology in a characteristic distribution. CTE must be clearly differentiated from tau astrogliopathy detected in the brains of neurologically normal elderly individuals, so-called "aging related tau astrogliopathy” (ARTAG) (Kovacs et al. 2016). ARTAG usually takes the form of thorn-shaped astrocytes in subpial and perivascular spaces in the mediobasal forebrain (Schultz et al. 2004), but fuzzy or granular astrocytes can be detected in gray matter structures, such as the amygdala (Fig. 3C,D).

\section{Progressive Supranuclear Palsy}

PSP is a tauopathy that often presents with atypical parkinsonism with vertical gaze palsy and early unexplained falls, but other clinical presentations are increasingly recognized (Williams and Lees 2009; Dickson et al. 2010). Pathologically, PSP is characterized by abnormal tau within neurons and glia (Fig. 4A-D). Biochemically, it is enriched in $4 \mathrm{R}$ tau isoforms (Buee et al. 2000), and there are characteristic low molecular weight cleavage fragments that differentiate PSP from other 4R tauopathies (Arai et al. 2004). The macroscopic findings in PSP include variable (usually mild) frontal cortical atrophy, atrophy of the subthalamic nucle- 


\section{B.N. Dugger and D.W. Dickson}
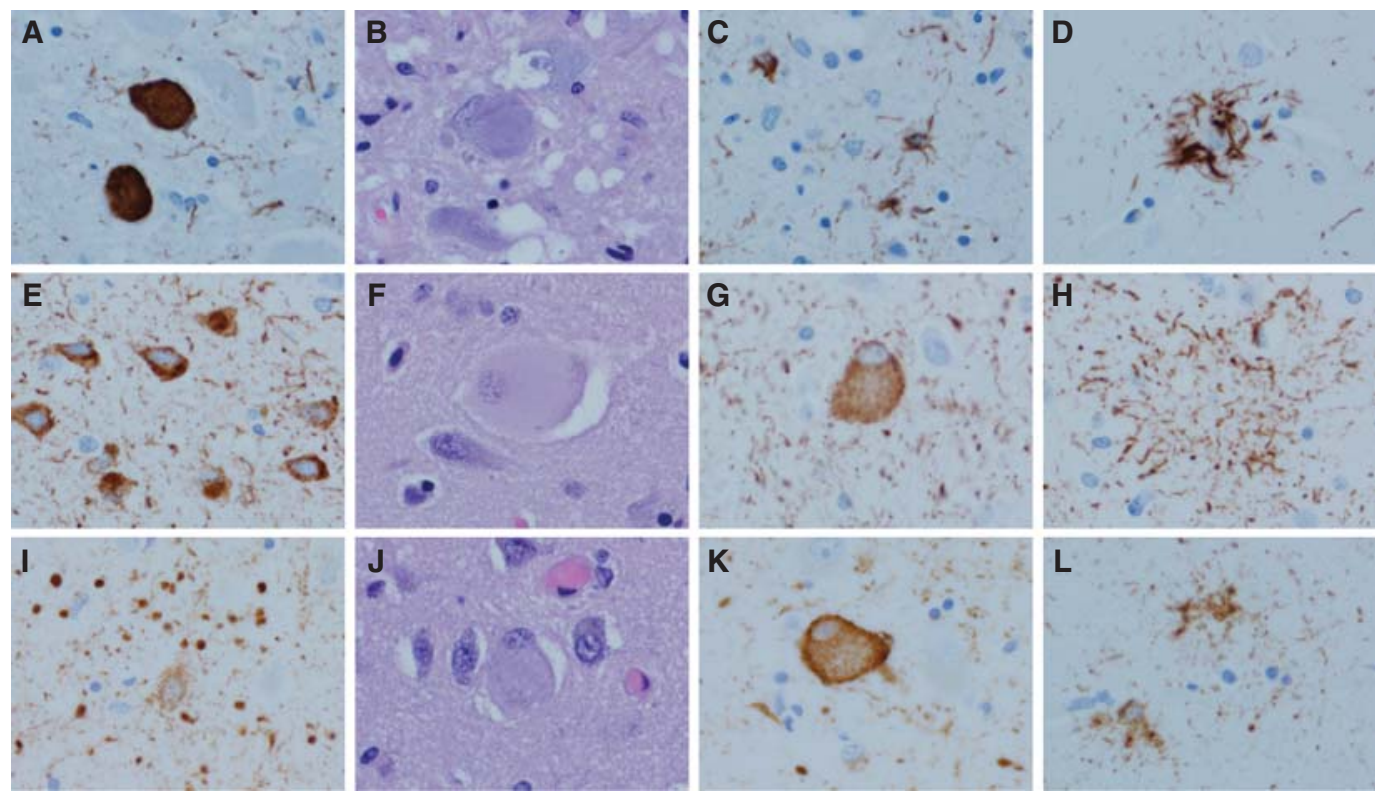

Figure 4. 4R tauopathies: Progressive supranuclear palsy (PSP) $(A-D)$, corticobasal degeneration $(\mathrm{CBD})(E-$ $H$ ), and argyrophilic grain disease (AGD) $(I-L)$. In PSP, the typical neuronal lesion is a globose NFT visible with phospho-tau immunohistochemistry $(A)$ or with hemotoxylin and eosin $(\mathrm{H} \& \mathrm{E})(B)$. Oligodendroglial coiled bodies $(C)$ and tufted astrocytes $(D)$ are typical glial lesions in PSP. In CBD, the typical neuronal lesion is a pretangle visible with tau immunohistochemistry $(E)$. Cortical neurons with ballooning degeneration can be detected with H\&E $(F)$ and phospho-tau $(G)$. The typical astrocytic lesion is the astrocytic plaque $(H)$, characterized by tau accumulation in distal processes of astrocytes. In AGD, the defining lesions are round to spindle-shaped grains $(I)$ that are most abundant in limbic areas. There are also pretangles. Ballooned neurons similar to those in CBD are also detected in limbic areas with $\mathrm{H} \& \mathrm{E}(J)$ and phospho-tau $(K)$. Tau-positive astrocytes are frequent, and they have ramified granular tau in cell processes $(L)$. (Immunohistochemistry with CP13, whose epitope is near phosphoserine 202.)

us, atrophy of the midbrain with neuromelanin pigment loss in the substantia nigra, and atrophy of the cerebellar dentate nucleus and the superior cerebellar peduncle. The characteristic microscopic findings are globose NFTs (Fig. 4A, $\mathrm{B})$ in subcortical nuclei, oligodendroglial "coiled bodies" (Fig. 4C) in affected white matter, and tufted astrocytes (Fig. 4D). Tufted astrocytes are frequent in the motor cortex and neostriatum, but sparse in other affected regions. Neuronal loss is most marked in the substantia nigra and subthalamic nucleus, with variable neuronal loss in the globus pallidus and cerebellar dentate nucleus. Neuronal loss correlates with vulnerability to neuronal, not astroglial, tau pathology. Tau also accumulates in neuronal and glial processes ("threads") in the affected brain regions.

\section{Corticobasal Degeneration}

$\mathrm{CBD}$ is a tauopathy with degeneration in frontoparietal association cortices and the basal ganglia, and was first recognized as a distinct entity ("cortico-dentato-nigral degeneration with neuronal achromasia") in 1968 (Rebeiz et al. 1968). The term "CBD" was coined in 1989 by Gibb et al. (1989). The clinical presentation is often a focal cortical syndrome, such as progressive aphasia or progressive asymmetrical apraxia ("corticobasal syndrome"). Many patients also have atypical parkinsonism. The original neuropathologic descriptions focused on cortical neurons with chromatolytic-like changes, also referred to as "ballooned neurons" (Fig. 4F,G). Tau pathology was recognized as a critical component only later (Ikeda et al. 1994; 
Feany and Dickson 1995). In addition to variable tau immunoreactivity (Fig. 4G), ballooned neurons are immunoreactive for neurofilament and $\alpha$-B-crystallin (Dickson et al. 2002). They are not only found in cortices that have focal atrophy but also in the cingulate gyrus, amygdala, and claustrum, where they can be found in other age-related disorders as well, such as argyrophilic grin disease (AGD). Characteristic tau astrocytic lesions, astrocytic plaques (Fig. $4 \mathrm{H}$ ), are abundant in affected cortices and the neostriatum. They are named because of their superficial resemblance to the neuritic plaques of $\mathrm{AD}$; however, astrocytic plaques are not associated with extracellular amyloid (Feany and Dickson 1995). The most common neuronal lesion is a poorly formed cytoplasmic inclusion ("pretangle," Fig. 4E) that is weakly stained or negative with traditional histologic methods used to detect NFTs in AD. Neuronal and glial lesions in CBD are enriched in 4R tau (Spillantini and Goedert 2013).

Neuropathologic criteria for CBD require neuronal, glial, and thread pathology in the gray and white matter of cortical and subcortical areas (Dickson et al. 2002). Ballooned neurons are supportive. Given the heterogeneity of the cortical involvement and the fact that other disorders can cause focal cortical degenerations (e.g., atypical $\mathrm{AD}$ ), the antemortem diagnostic accuracy of $\mathrm{CBD}$ is poor, and recent clinical criteria reflect this fact (Armstrong et al. 2013). Although clinical syndromes associated with $\mathrm{CBD}$ are often asymmetric, patients with symmetrical cortical deficits are increasingly recognized (Hassan et al. 2010). Symmetrical CBD patients are clinically difficult to differentiate from PSP, but they have distinctive pathologic and biochemical findings (Kouri et al. 2011).

\section{Argyrophilic Grain Disease}

AGD was originally reported as a distinct tauopathy (Braak and Braak 1987) and thought to be associated with dementia and behavioral disturbances (Tolnay and Clavaguera 2004). However, recent studies have questioned the specificity of this clinical syndrome, as it is associated with mild cognitive impairment (Petersen et al 2006) and its main effect is to modify the phenotype of the disorder in which it occurs (Josephs et al. 2008c). AGD increases with age and can be detected in up to $50 \%$ of individuals over 80 years of age (Togo et al. 2002a). It is found frequently in other $4 \mathrm{R}$ tauopathies-20\% in PSP and 40\% in CBD (Togo et al. 2002a). The characteristic lesions are spindle-shaped tauimmunoreactive lesions ("grains") in neuronal processes (Fig. 4I), coiled bodies in oligodendrocytes, ramified astrocytes in the amygdala (Fig. 4L), and variably tau-positive ballooned neurons (Fig. 4J, K) in the entorhinal cortex and other limbic areas (Tolnay and Probst 1998). Biochemically, AGD is associated with accumulation of 4R tau (Togo et al. 2002b).

\section{Pick's Disease}

Pick's disease is a rare neurodegenerative tauopathy originally described by Pick in 1892 and described neuropathologically in 1911 by Alzheimer ( for historical review, see Constantinidis et al. 1974). Macroscopically, Pick's disease has sharply circumscribed, severe ("knife-edge") gyral atrophy of the frontal and temporal lobes, with ventricular enlargement and variable atrophy of the neostriatum (Dickson 1998). Limbic structures (e.g., hippocampus and amygdala) are often severely affected. Depending on the distribution of the cortical atrophy (which is often asymmetrical), Pick's disease presents clinically with focal cortical syndromes, such as behavioral variant frontotemporal dementia, progressive aphasia, or even corticobasal syndrome. Some cases have involvement of neuromelanin-containing neurons in the brainstem, but parkinsonism is uncommon.

Microscopically, the defining histologic feature of Pick's disease is the intraneuronal taupositive Pick body (Fig. 5B,D), which affects both pyramidal (Fig. 5A,B) and granular-type neurons, such as the neurons of the dentate fascia of the hippocampus (Fig. 5C,D). The tau isoform that preferentially accumulates in Pick's disease is 3R tau (Buee et al. 2000). Pick bodies are spherical inclusions that are clearly demarcated from the cytoplasm and readily de- 
B.N. Dugger and D.W. Dickson
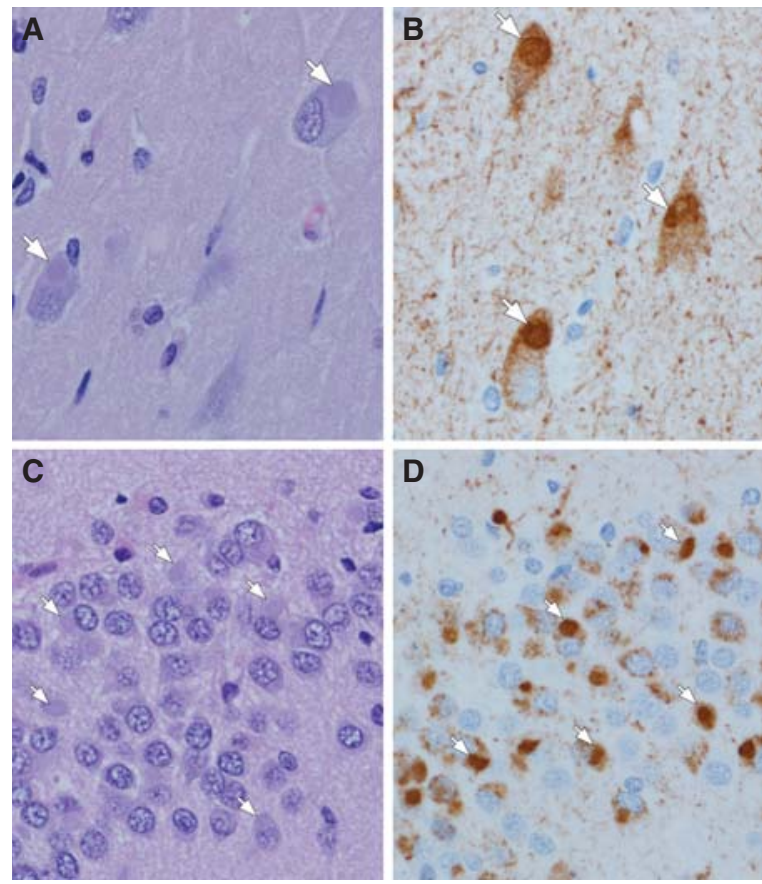

Figure 5. 3R tauopathy: Pick's disease $(A-D)$. Pick bodies are slightly basophilic, well-circumscribed cytoplasmic inclusions (arrows) that can be detected in pyramidal neurons of the hippocampus $(A, B)$ and granule neurons of the dentate fascia $(C, D)$ (arrows). Hemotoxylin and eosin (H\&E) reveals cytoplasmic inclusions $(A, C)$, whereas phospho-tau immunohistochemistry shows not only Pick bodies (arrows), but also diffuse cytoplasmic immunoreactivity and immunoreactivity in fine neuropil threads $(B, D)$. (Immunohistochemistry with CP13, whose epitope is near phosphoserine 202.)

tected on hemotoxylin and eosin (H\&E) histological stains (Fig. 5A,C). They are argyrophilic with most silver stains (e.g., Bielschowsky and Bodian stains), but they are negative with the Gallyas silver stain (Uchihara et al. 2005). As in other neurodegenerative diseases, in Pick's disease there is neuronal loss and gliosis in affected cortical areas. Ballooned neurons ("Pick cells") are frequent as well.

\section{SYNUCLEINOPATHIES}

This class of neurodegenerative diseases is characterized by aggregation of the presynaptic protein, $\alpha$-synuclein, within neurons and glia (mostly oligodendroglia) (Fig. 6). It is a 140amino-acid protein initially discovered as a non-amyloid component of senile plaques (NACP) in AD (Ueda et al. 1993). It may play a role in synaptic vesicle trafficking (Sudhof and Rizo 2011). In 1997, mutations in the gene for $\alpha$-synuclein, $S N C A$, were discovered in familial PD (Polymeropoulos et al. 1997). Subsequently, $\alpha$-synuclein was demonstrated to be the major constituent of Lewy bodies (Spillantini et al. 1997). Lewy bodies are neuronal inclusions found in a range of clinical syndromes, including PD, PD with dementia, and DLB. In addition to Lewy body disorders, pathological accumulation of $\alpha$-synuclein is found in multiple system atrophy (MSA) (Lantos 1998). In MSA, the aggregates are mostly within oligodendrocytes (Fig. 6H), whereas in Lewy body diseases, they are predominantly within neurons (Fig. 6B). In addition to perikaryal Lewy bodies, there is accumulation of $\alpha$ synuclein in neurites ("Lewy neurites") (Fig. 6C) (Irizarry et al. 1998), and oligodendroglial inclusions are frequently present in small numbers (Fig. 6D). 

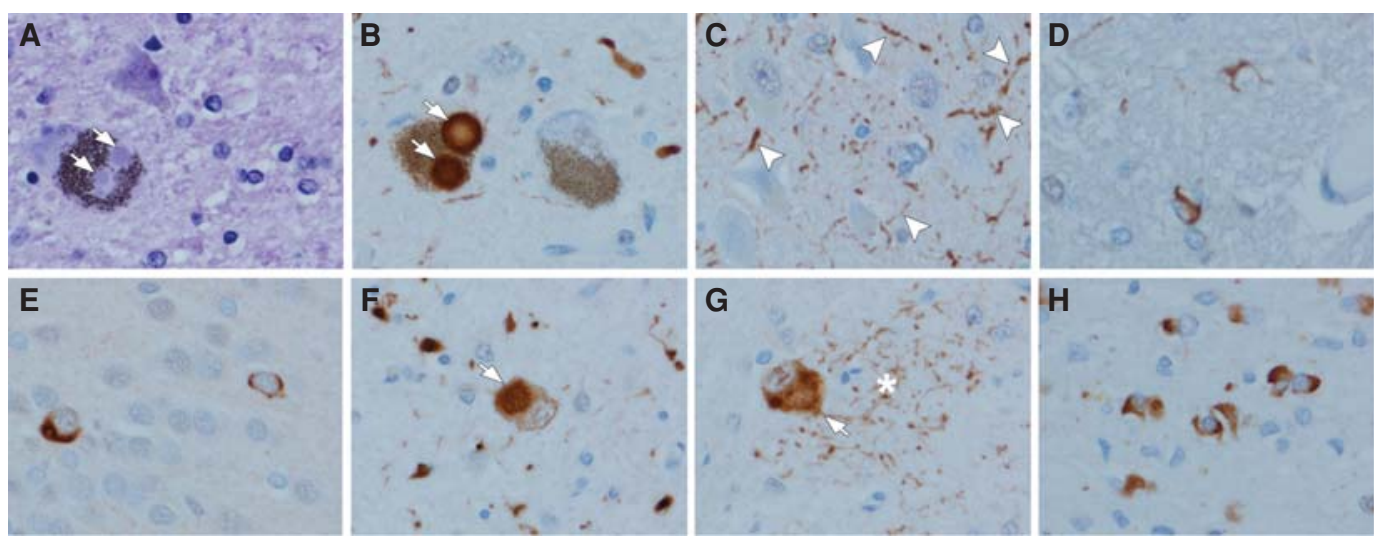

Figure 6. Synucleinopathies: Lewy body disease $(A-D)$ and multiple system atrophy (MSA) $(E-H)$. Brainstemtype Lewy bodies are hyaline inclusions (arrows) that can be detected in neuromelanin-containing neurons of the substantia nigra upon hemotoxylin and eosin (H\&E) (A) or with $\alpha$-synuclein immunohistochemistry (arrows) (B). In addition to Lewy bodies, $\alpha$-synuclein immunohistochemistry reveals Lewy neurites (arrowheads), for example, in the CA2/3 sector of the hippocampus $(C)$. Sparse oligodendroglial inclusions can be detected in the basal ganglia and the ventral tegmental region of the midbrain in most cases $(D)$. Neuronal cytoplasmic inclusions are detected in MSA with $\alpha$-synuclein immunohistochemistry. They are infrequent in the dentate fascia of the hippocampus $(E)$, and frequent in neurons of the pontine nuclei (arrow) $(F)$, and the inferior olivary nucleus (arrow) $(G)$. Neuronal inclusions are usually accompanied by dystrophic neurites (asterisk in $G$ ). The hallmark lesions of MSA are $\alpha$-synuclein-immunoreactive glial cytoplasmic inclusions in affected white matter of the basal ganglia, brainstem, or cerebellum $(H)$. (Immunohistochemistry with polyclonal $\alpha$-synuclein antibody $[\mathrm{NACP}]$ specific to an epitope in the $\mathrm{C}$-terminus corresponding to residues 98 -15.)

\section{Lewy Body Disorders}

Clinically diagnosed PD, PD with dementia, and DLB are considered Lewy body disorders, as Lewy bodies are detected in most cases on postmortem examination. Lewy body disorders are more common in men for reasons that remain unexplained. In addition to dementia and parkinsonism, many patients have autonomic dysfunction, sleep disorders, and psychiatric features (e.g., visual hallucinations). At autopsy, there is often minimal, if any, neocortical or brainstem atrophy. The most significant findings are noted upon sectioning the brainstem, where there is loss of neuromelanin pigment in the substantia nigra and locus coeruleus.

There are two main histologic types of Lewy bodies, which are named according to their predominant anatomic location-brainstem-type Lewy bodies, which have a dense, well-circumscribed, hyaline appearance, often with a clear halo (Fig. 6A,B), and cortical-type, which are pale-staining and poorly circumscribed. Prote- omic studies have demonstrated that Lewy bodies contain over 300 different proteins (Leverenz et al. 2007), with the defining feature being $\alpha$ synuclein. Other components that have been reported are neurofilament (Galvin et al. 1997) and the ubiquitin-binding protein $\mathrm{p} 62$ /sequestosome (Kuusisto et al. 2003). A subset of Lewy bodies shows immunoreactivity with antibodies to tau (Ishizawa et al. 2003), but this is almost always in neuronal populations that are inherently vulnerable to tau pathology. Other studies have demonstrated neurotransmitter synthetic enzymes within Lewy bodies (Dugger and Dickson 2010). The factors that lead to abnormal conformation of $\alpha$-synuclein remain to be determined, but several posttranslational modifications, including phosphorylation, truncation, and oxidative damage, are implicated (reviewed in Dickson 2001).

A pathological classification of Lewy body diseases was first proposed by Kosaka et al. (1984) to characterize patients who had psychiatric or cognitive deficits, rather than predom- 
inantly parkinsonism. He defined three types of Lewy body disease: brainstem predominant, limbic (transitional), and diffuse cortical. The diffuse cortical type usually presented with dementia. The Kosaka classification has been incorporated into diagnostic criteria for DLB (McKeith et al. 2005), and it is also recommended for the classification of Lewy-related pathology in the setting of AD (Montine et al. 2012). Lewy bodies and Lewy neurites, sometimes collectively termed "Lewy-related pathology," have a stereotypical distribution when found in the setting of $\mathrm{PD}$, which led Braak to propose a staging scheme for PD (Braak et al. 2003). Early pathology was in the olfactory bulb and medulla, followed by upward progression through the brainstem to the mediobasal forebrain and limbic structures and finally to the association and primary cortices. A modification of Braak PD staging is recommended by BrainNet Europe (Alafuzoff et al. 2009a).

Although these staging or classification schemes are useful constructs, they fail to classify up to $50 \%$ of elderly subjects with Lewyrelated pathology. The disparate staging and classification schemes suggest that there is not a single pathway to neurodegeneration in Lewyrelated disorders. PD may have initial $\alpha$-synuclein aggregates in the brainstem, or even within the peripheral autonomic nervous system, whereas initial $\alpha$-synuclein aggregates in $\mathrm{AD}$ and DLB may be in olfactory and limbic areas (Uchikado et al. 2006b; Beach et al. 2009).

This led to a "unified Lewy body staging scheme" (Beach et al. 2009) with the following hierarchical staging: 0 , no Lewy bodies; I, olfactory bulb only; IIa, brainstem predominant; IIb, limbic predominant; III, brainstem and limbic; and IV, neocortical. More recently, Toledo and colleagues (2016) have proposed a modification based on cluster analysis of a large number of cases of AD with Lewy bodies.

Most cases of DLB and PD with dementia have diffuse involvement of the cerebral cortex (Halliday et al. 2008, 2011). It is critical to note that many Lewy body disorders, especially DLB and PD with dementia, have concomitant ADtype pathology (Dugger et al. 2014a). Roughly half of PD with dementia is hypothesized to be because of progression of the underlying coexistent AD (Dugger et al. 2012). Furthermore, the 2005 diagnostic criteria for DLB take into account both Lewy-related and AD-type pathologies to predict the likelihood that the observed pathology would be associated with the DLB clinical syndrome (McKeith et al. 2005).

\section{Multiple System Atrophy}

MSA, historically known as olivopontocerebellar atrophy (OPCA), striatonigral degeneration, or Shy-Drager syndrome, is clinically and pathologically divided into two subtypes: olivopontocerebellar atrophy, presenting with cerebellar ataxia (MSA-C), and striatonigral degeneration, presenting with atypical parkinsonism (MSA$\mathrm{P})$. In both subtypes, there is significant and often disabling autonomic dysfunction (Gilman et al. 2008). A subset of patients has features of both MSA-C and MSA-P. Despite clinical and pathological differences, the subtypes of MSA share pathognomonic $\alpha$-synuclein inclusions in oligodendrocytes known as glial cytoplasmic inclusions (Lantos 1998).

Depending on the subtype, macroscopic findings differ. In striatonigral degeneration, there is atrophy and discoloration of the posterolateral putamen with depigmentation of the substantia nigra, especially the ventrolateral regions. There is also excessive iron-type pigment in the putamen. In olivopontocerebellar degeneration, there is atrophy of the pontine base with demyelination of the middle and inferior cerebellar peduncles, often with mild atrophy of the inferior olivary nucleus and the cerebellum, especially the vermis. The affected white matter often has atrophy and dusky gray discoloration. Although the pathognomic lesion of MSA is the glial cytoplasmic inclusion (Fig. 6H), neuronal cytoplasmic inclusions are also found in the putamen, the nuclei of the pontine base (Fig. $6 \mathrm{~F}$ ), and the inferior olivary nucleus (Fig. 6G), and less often in limbic structures, such as the dentate gyrus of the hippocampus (Fig. 6E) (Cykowski et al. 2015). Some evidence supports that $\alpha$-synuclein deposits within MSA have prion properties, as demonstrated by their trans- 
missibility to transgenic mice and cultured cells (Watts et al. 2013; Prusiner et al. 2015).

\section{TDP-43 PROTEINOPATHIES}

TDP-43 is a $43-\mathrm{kDa}$ protein that can function in transcriptional repression, modulating gene splicing, RNA metabolism, and stress granules (Ratti and Buratti 2016). In 2006, TDP-43 was discovered to be the major component of neuronal inclusions in ALS and frontotemporal lobar degeneration with ubiquitin inclusions (Neumann et al. 2006), now referred to as
FTLD-TDP. TDP-43 is normally a nuclear protein, but in neurodegenerative diseases, it forms inclusion bodies in the cytoplasm, nucleus, and cell processes (Fig. 7). In addition to ALS and FTLD-TDP, abnormal TDP-43 can be detected in $25 \%$ to $50 \%$ of $\mathrm{AD}$ cases, mainly in a limbic distribution (Amador-Ortiz et al. 2007; Hu et al. 2008; Josephs et al. 2014), and in even higher frequencies in AGD cases (Fujishiro et al. 2009; Arnold et al. 2013). In addition, although not pathognomonic, TDP-43 is detected in the majority of cases of hippocampal sclerosis of the elderly, which is characterized by selective neu-
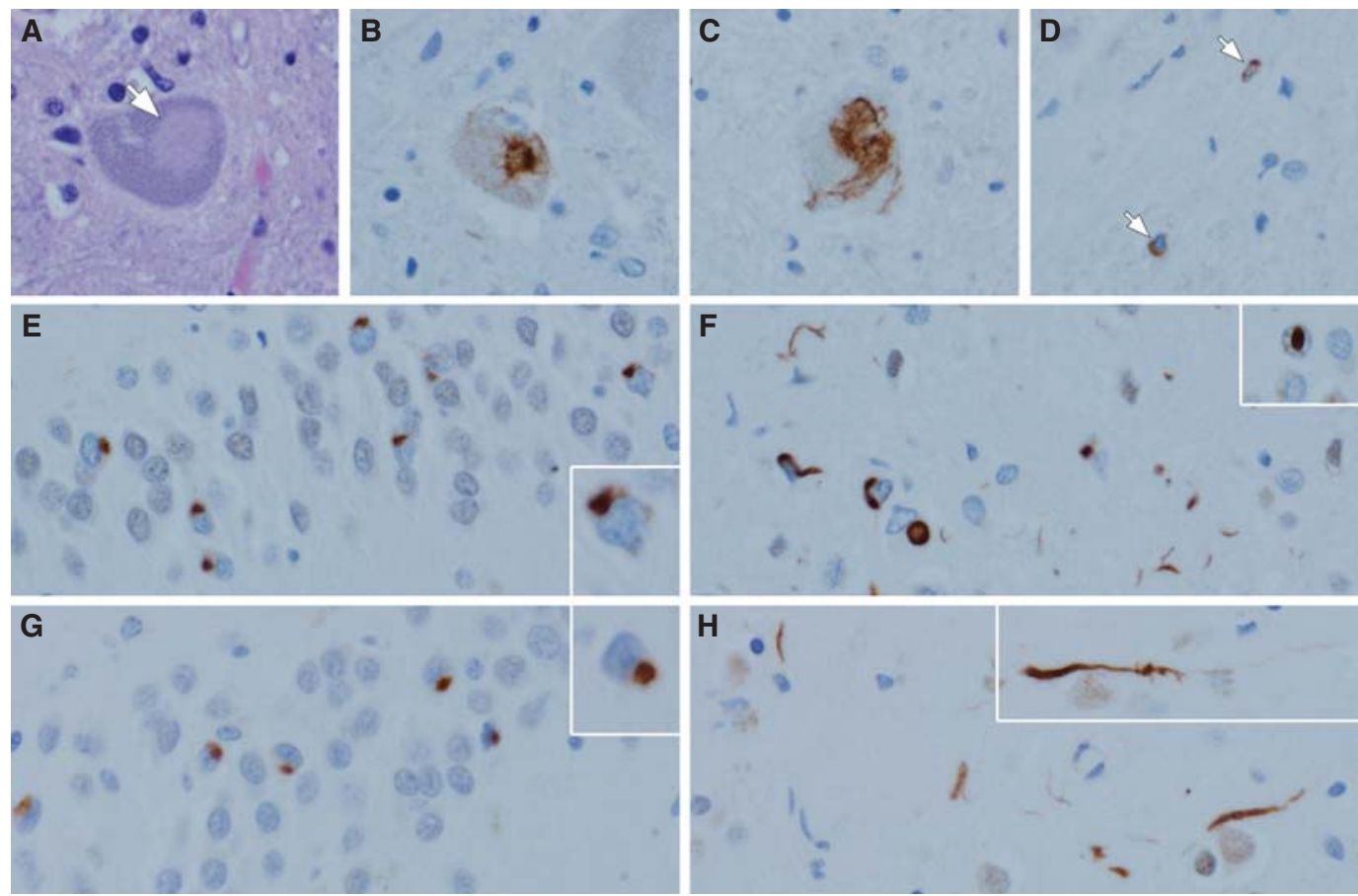

Figure 7. Transactivation response DNA binding protein 43 (TDP-43) proteinopathies: amyotrophic lateral sclerosis (ALS) $(A-D)$ and frontotemporal lobar degeneration with TDP-43 neuronal inclusions (FTLDTDP) $(F-H)$. In ALS, Lewy-like hyaline inclusions (arrow) can be detected in anterior horn cells of the spinal cord $(A)$. Immunohistochemistry for TDP-43 reveals dense inclusions $(B)$ and skein-like inclusions $(C)$ in motor neurons of the brainstem and spinal cord. White matter motor tracts often have sparse TDP-43-immunoreactive oligodendroglial inclusions (arrows) $(D)$. In FTLD-TDP Type A, neurons of the dentate fascia often have granular or ring-shaped neuronal cytoplasmic inclusions $(E$, inset $)$, whereas the affected cortices have more pleomorphic neuronal cytoplasmic inclusions, short curved dystrophic neurites, and neuronal intranuclear inclusions $(F$, inset). In FTLD-TDP Type $C$, round, well-circumscribed (Pick-body-like) neuronal cytoplasmic inclusions are frequent in the dentate fascia of the hippocampus $(G)$, whereas they are sparse in the affected cortices, where long, thick dystrophic neurites ( $H$, inset) are the most characteristic feature. Type B (not shown) has predominantly neuronal cytoplasmic inclusions with minimal dystrophic neurites and no intranuclear inclusions. (TDP-43 immunohistochemistry with polyclonal MC2085 antibody to a neoepitope in caspasecleaved TDP-43.) 
B.N. Dugger and D.W. Dickson

ronal loss affecting the CA1 sector of the hippocampus and is associated with an amnestic clinical syndrome (Amador-Ortiz et al. 2007).

\section{Amyotrophic Lateral Sclerosis}

ALS affects both upper and lower motor neurons and clinically is associated with weakness, muscle atrophy, and fasciculations, as well as longtract signs ("spasticity"). ALS can be subtyped based on the relative involvement of primarily upper motor neurons (primary lateral sclerosis) or primarily lower motor neurons (progressive muscle atrophy). It can also be classified based on neuroanatomical distribution (e.g., bulbar and spinal forms). A subset of patients develops dementia that has many characteristics in common with FTD (Lomen-Hoerth et al. 2002). Most ALS is associated with TDP-43 pathology, but less common forms have other characteristic molecular signatures (Ince et al. 2011).

The macroscopic findings in ALS are often subtle. There may be mild atrophy of the motor cortex, and the spinal cord is often atrophic, with atrophy of anterior spinal nerve roots. In patients with dementia, there may be focal atrophy of the temporal and frontal lobes. Microscopically, there is neuronal loss and gliosis affecting the lower motor neurons in the spinal cord and brainstem, as well as the upper motor neurons (Betz cells) in the motor cortex. Surviving neurons often have TDP-43 inclusions that can sometimes be seen in routine histologic sections (Fig. 7A); they are best viewed with TDP-43 immunohistochemistry (Fig. 7B). Neuronal inclusions can also have a skein-like appearance (Fig. 7C). There are often sparse oligodendroglial inclusions in motor tracts (Fig. 7D). Although motor neurons are most vulnerable, there is spread of the pathology to extramotor sites (e.g., hippocampus, amygdala, and cortex) in cases with longstanding disease or in those with dementia (Brettschneider et al. 2013).

\section{FTLD-TDP}

The most common pathological type of frontotemporal dementia is associated with TDP-43 pathology. Less common forms of FTLD have other characteristic molecular signatures (Mackenzie et al. 2010; Mackenzie and Neumann 2016), but this discussion focuses only on FTLD-TDP. There are several clinical presentations: behavioral variant, progressive agrammatic (nonfluent) aphasia, and progressive aphasia, semantic variant (Bang et al. 2015). The macroscopic appearance of FTLD-TDP depends on the clinical presentation, but often has frontal and temporal neocortical atrophy, often with neostriatal atrophy and substantia nigra depigmentation. There are three major types of TDP-43 inclusions: neuronal cytoplasmic inclusions, dystrophic neurites, and neuronal intranuclear inclusions (Fig. 7E-H). Shortly after the discovery of TDP-43, two groups described neuroanatomical and morphological subtype inclusions in FTLD (Mackenzie et al. 2006; Sampathu et al. 2006). These two systems were combined in 2011 into a single classification scheme (Mackenzie et al.2011). Type A is the most common type in patients with mutations in the progranulin gene $(G R N)$ who present clinically with either progressive nonfluent aphasia or behavioral variant FTD. TDP-43 is present in coarsely granular neuronal cytoplasmic inclusions in hippocampal dentate fascia (Fig. 7E and inset) and present in more variable neuronal cytoplasmic inclusions in the neocortex (Fig. 7F). There are also short, thin dystrophic neurites in superficial layers of the cortex (Fig. 7F), as well as variable numbers of neuronal intranuclear inclusions (inset in Fig. 7F). Type B, which can be associated with motor neuron disease, is predominantly characterized by neuronal cytoplasmic inclusions with few or no neurites and no neuronal intranuclear inclusions, as occurs most commonly in patients with hexanucleotide expansions in the C9ORF72 gene (DeJesus-Hernandez et al. 2011; Renton et al. 2011). Type $\mathrm{C}$ is not associated with genetic mutations, and patients usually present with a semantic variant of progressive aphasia. This type is characterized by long, thick dystrophic neurites randomly oriented in all cortical layers (Fig. 7H and inset). Well-circumscribed (Pick-body-like) neuronal cytoplasmic inclusions are found in the hippocampus, amygdala, and basal ganglia (Fig. 
Pathology of Neurodegenerative Diseases

7G and inset) (Josephs et al. 2008a). A fourth type, Type D, is rare and associated with mutations in the valosin-containing protein (VCP) and presenting with inclusion body myositis, Paget's disease of bone, and frontotemporal dementia (Neumann et al. 2007; Weihl et al. 2008). Type $\mathrm{D}$ is characterized by numerous neuronal intranuclear inclusions in cortical and subcortical areas.

\section{CONCLUDING REMARKS}

Although, in this review, each neurodegenerative disease is presented as a distinct entity, there is often overlap, most notably for $\mathrm{AD}$ and Lewy body pathologies. None of the neurodegenerative disorders have perfect diagnostic accuracy, and neuropathology will continue to be the gold standard for the foreseeable future. Studying disease heterogeneity at autopsy is key to understanding discrepancies between clinical and pathological diagnoses (Hughes et al. 1992; Josephs and Dickson 2003; Beach et al. 2012; Adler et al. 2014). This is a critical concept because there are many efforts to develop biomarkers to diagnose these diseases and to monitor disease progression in clinical trials. Many studies dichotomize only on the presence or absence of the clinical syndrome. The increasing complexity of neuropathological findings necessitates that all aspects of the antemortem clinical picture, not just the key cardinal signs or symptoms, be considered to study their molecular and structural correlates (Armstrong et al. 2005; Selikhova et al. 2009; Halliday et al. 2011; Murray et al. 2011; Dugger et al. 2014a,b; Thenganatt and Jankovic 2014). Neuropathologists need not only to make diagnoses, but also to collect standardized clinical, pathological, and genetic characteristics of their patients. At a minimum, this should include age of onset, symptom duration, clinical diagnosis, clinical indices of disease severity, and the density and distribution of the various pathologic processes. These are all critical factors to consider, as pathological heterogeneity may affect statistical power and significance, and perceived effect sizes in clinical trials and biomarker studies.

\section{ACKNOWLEDGMENTS}

D.W.D. is supported by grants AG037491 (PI: Josephs), NS084974 (PI: Petrucelli), NS072187 (PI: Dickson), and AG016574 (PI: Petersen) from the National Institutes of Health, as well as the Robert E. Jacoby Professorship and the Mangurian Foundation Lewy Body Dementia Program at Mayo Clinic. B.N.D. is supported by grants AG002132 (Core C) (PI: Dugger) from the National Institutes of Health, as well as the CurePSP foundation (PI: Dugger), the Henry M. Jackson Foundation (HU0001-152-0020, PI: Prusiner), and Daiichi Sankyo Co., Ltd. (PI: Prusiner).

\section{REFERENCES}

* Reference is also in this collection.

Adler CH, Connor DJ, Hentz JG, Sabbagh MN, Caviness JN Shill HA, Noble B, Beach TG. 2010. Incidental Lewy body disease: Clinical comparison to a control cohort. Mov Disord 25: 642-646.

Adler CH, Beach TG, Hentz JG, Shill HA, Caviness JN, Driver-Dunckley E, Sabbagh MN, Sue LI, Jacobson SA, Belden CM, et al. 2014. Low clinical diagnostic accuracy of early vs. advanced Parkinson disease: Clinicopathologic study. Neurology 83: 406-412.

Alafuzoff I, Ince PG, Arzberger T, Al-Sarraj S, Bell J, Bodi I, Bogdanovic N, Bugiani O, Ferrer I, Gelpi E, et al. 2009a. Staging/typing of Lewy body related $\alpha$-synuclein pathology: A study of the BrainNet Europe Consortium. Acto Neuropathol 117: 635-652.

Alafuzoff I, Thal DR, Arzberger T, Bogdanovic N, Al-Sarraj S, Bodi I, Boluda S, Bugiani O, Duyckaerts C, Gelpi E, et al. 2009b. Assessment of $\beta$-amyloid deposits in human brain: A study of the BrainNet Europe Consortium. Acta Neuropathol 117: 309-320.

Alafuzoff I, Pikkarainen M, Neumann M, Arzberger T, AlSarraj S, Bodi I, Bogdanovic N, Bugiani O, Ferrer I, Gelpi E, et al. 2015. Neuropathological assessments of the pathology in frontotemporal lobar degeneration with TDP43-positive inclusions: An inter-laboratory study by the BrainNet Europe consortium. J Neural Transm (Vienna) 122: 957-972.

Alonso AC, Li B, Grundke-Iqbal I, Iqbal K. 2008. Mechanism of tau-induced neurodegeneration in Alzheimer disease and related tauopathies. Curr Alzheimer Res 5: 375-384.

Amador-Ortiz C, Lin WL, Ahmed Z, Personett D, Davies P, Duara R, Graff-Radford NR, Hutton ML, Dickson DW. 2007. TDP-43 immunoreactivity in hippocampal sclerosis and Alzheimer's disease. Ann Neurol 61: 435445.

Andreadis A. 2005. Tau gene alternative splicing: Expression patterns, regulation and modulation of function in nor- 
B.N. Dugger and D.W. Dickson

mal brain and neurodegenerative diseases. Biochim Biophys Acta 1739: 91-103.

Arai T, Ikeda K, Akiyama H, Nonaka T, Hasegawa M, Ishiguro K, Iritani S, Tsuchiya K, Iseki E, Yagishita S, et al. 2004. Identification of amino-terminally cleaved tau fragments that distinguish progressive supranuclear palsy from corticobasal degeneration. Ann Neurol 55: 72-79.

Armstrong RA, Lantos PL, Cairns NJ. 2005. Overlap between neurodegenerative disorders. Neuropathology 25: $111-124$.

Armstrong MJ, Litvan I, Lang AE, Bak TH, Bhatia KP, Borroni B, Boxer AL, Dickson DW, Grossman M, Hallett M, et al. 2013. Criteria for the diagnosis of corticobasal degeneration. Neurology 80: 496-503.

Arnold SJ, Dugger BN, Beach TG. 2013. TDP-43 deposition in prospectively followed, cognitively normal elderly individuals: Correlation with argyrophilic grains but not other concomitant pathologies. Acta Neuropathol 126: 51-57.

Bang J, Spina S, Miller BL. 2015. Frontotemporal dementia. Lancet 386: 1672-1682.

Beach TG, Adler CH, Lue L, Sue LI, Bachalakuri J, HenryWatson J, Sasse J, Boyer S, Shirohi S, Brooks R, et al. 2009. Unified staging system for Lewy body disorders: Correlation with nigrostriatal degeneration, cognitive impairment and motor dysfunction. Acta Neuropathol 117: 613-634.

Beach TG, Monsell SE, Phillips LE, Kukull W. 2012. Accuracy of the clinical diagnosis of Alzheimer disease at National Institute on Aging Alzheimer Disease Centers, 2005-2010. J Neuropathol Exp Neurol 71: 266-273.

Bieniek KF, Ross OA, Cormier KA, Walton RL, Soto-Ortolaza A, Johnston AE, DeSaro P, Boylan KB, Graff-Radford NR, Wszolek ZK, et al. 2015. Chronic traumatic encephalopathy pathology in a neurodegenerative disorders brain bank. Acta Neuropathol 130: 877-889.

Binder LI, Frankfurter A, Rebhun LI. 1985. The distribution of tau in the mammalian central nervous system. J Cell Biol 101: 1371-1378.

Braak H, Braak E. 1987. Argyrophilic grains: Characteristic pathology of cerebral cortex in cases of adult onset dementia without Alzheimer changes. Neurosci Lett 76: $124-127$.

Braak H, Braak E. 1991. Neuropathological stageing of Alzheimer-related changes. Acta Neuropathol 82: 239-259.

Braak H, Braak E, Grundke-Iqbal I, Iqbal K. 1986. Occurrence of neuropil threads in the senile human brain and in Alzheimer's disease: A third location of paired helical filaments outside of neurofibrillary tangles and neuritic plaques. Neurosci Lett 65: 351-355.

* Braak H, Del Tredici K. 2016. Potential pathways of abnormal tau and $\alpha$-synuclein dissemination in sporadic $\mathrm{Alz}$ heimer's and Parkinson's diseases. Cold Spring Harb Perspect Biol 8: a023630.

Braak H, Del Tredici K, Rub U, de Vos RA, Jansen Steur EN, Braak E. 2003. Staging of brain pathology related to sporadic Parkinson's disease. Neurobiol Aging 24: $197-$ 211.

Braak H, Thal DR, Ghebremedhin E, Del Tredici K. 2011. Stages of the pathologic process in Alzheimer disease: Age categories from 1 to 100 years. J Neuropathol Exp Neurol 70: 960-969.

Brettschneider J, Del Tredici K, Toledo JB, Robinson JL, Irwin DJ, Grossman M, Suh E, Van Deerlin VM, Wood EM, Baek Y, et al. 2013. Stages of pTDP-43 pathology in amyotrophic lateral sclerosis. Ann Neurol 74: 20-38.

Brettschneider J, Del Tredici K, Irwin DJ, Grossman M, Robinson JL, Toledo JB, Lee EB, Fang L, Van Deerlin VM, Ludolph AC, et al. 2014. Sequential distribution of pTDP-43 pathology in behavioral variant frontotemporal dementia (bvFTD). Acta Neuropathol 127: 423-439.

Budka H, Aguzzi A, Brown P, Brucher JM, Bugiani O, Gullotta F, Haltia M, Hauw JJ, Ironside JW, Jellinger K, et al. 1995. Neuropathological diagnostic criteria for Creutzfeldt-Jakob disease (CJD) and other human spongiform encephalopathies (prion diseases). Brain Pathol 5: 459466.

Buee L, Bussiere T, Buee-Scherrer V, Delacourte A, Hof PR. 2000. Tau protein isoforms, phosphorylation and role in neurodegenerative disorders. Brain Res Brain Res Rev 33: 95-130.

Constantinidis J, Richard J, Tissot R. 1974. Pick's disease. Histological and clinical correlations. Eur Neurol 11: 208-217.

Cook C, Stankowski JN, Carlomagno Y, Stetler C, Petrucelli L. 2014. Acetylation: A new key to unlock tau's role in neurodegeneration. Alzheimers Res Ther 6: 29.

Crary JF, Trojanowski JQ, Schneider JA, Abisambra JF, Abner EL, Alafuzoff I, Arnold SE, Attems J, Beach TG, Bigio EH, et al. 2014. Primary age-related tauopathy (PART): A common pathology associated with human aging. Acta Neuropathol 128: 755-766.

Cykowski MD, Coon EA, Powell SZ, Jenkins SM, Benarroch EE, Low PA, Schmeichel AM, Parisi JE. 2015. Expanding the spectrum of neuronal pathology in multiple system atrophy. Brain 138: 2293-2309.

DeJesus-Hernandez M, Mackenzie IR, Boeve B, Boxer Al, Baker M, Rutherford NJ, Nicholson AM, Finch NA, Flynn H, Adamson J, et al. 2011. Expanded GGGGCC hexanucleotide repeat in noncoding region of C9ORF72 causes chromosome 9p-linked FTD and ALS. Neuron 72: 245-256.

Dickson DW. 1997. The pathogenesis of senile plaques. $J$ Neuropathol Exp Neurol 56: 321-339.

Dickson DW. 1998. Pick's disease: A modern approach. Brain Pathol 8: 339-354.

Dickson DW. 2001. $\alpha$-Synuclein and the Lewy body disorders. Curr Opin Neurol 14: 423-432.

Dickson DW, Bergeron C, Chin SS, Duyckaerts C, Horoupian D, Ikeda K, Jellinger K, Lantos PL, Lippa CF, Mirra SS, et al. 2002. Office of Rare Diseases neuropathologic criteria for corticobasal degeneration. J Neuropathol Exp Neurol 61: 935-946.

Dickson DW, Ahmed Z, Algom AA, Tsuboi Y, Josephs KA. 2010. Neuropathology of variants of progressive supranuclear palsy. Curr Opin Neurol 23: 394-400.

Dickson DW, Kouri N, Murray ME, Josephs KA. 2011. Neuropathology of frontotemporal lobar degeneration-tau (FTLD-tau). J Mol Neurosci 45: 384-389. 
Dugger BN, Dickson DW. 2010. Cell type specific sequestration of choline acetyltransferase and tyrosine hydroxylase within Lewy bodies. Acta Neuropathol 120: 633-639.

Dugger BN, Serrano GE, Sue LI, Walker DG, Adler CH, Shill HA, Sabbagh MN, Caviness JN, Hidalgo J, Saxon-Labelle M, et al. 2012. Presence of striatal amyloid plaques in Parkinson's disease dementia predicts concomitant Alzheimer's disease: Usefulness for amyloid imaging. J Parkinsons Dis 2: 57-65.

Dugger BN, Adler CH, Shill HA, Caviness J, Jacobson S, Driver-Dunckley E, Beach TG. 2014a. Concomitant pathologies among a spectrum of parkinsonian disorders. Parkinsonism Relat Disord 20: 525-529.

Dugger BN, Clark CM, Serrano G, Mariner M, Bedell BJ, Coleman RE, Doraiswamy PM, Lu M, Fleisher AS, Reiman EM, et al. 2014b. Neuropathologic heterogeneity does not impair florbetapir-positron emission tomography postmortem correlates. J Neuropathol Exp Neurol 73: $72-80$.

Dugger BN, Hentz JG, Adler CH, Sabbagh MN, Shill HA, Jacobson S, Caviness JN, Belden C, Driver-Dunckley E, Davis KJ, et al. 2014c. Clinicopathological outcomes of prospectively followed normal elderly brain bank volunteers. J Neuropathol Exp Neurol 73: 244-252.

Ellison D. 2013. Neuropathology: A reference text of CNS pathology. Mosby, Edinburgh.

Espinoza M, de Silva R, Dickson DW, Davies P. 2008. Differential incorporation of tau isoforms in Alzheimer's disease. J Alzheimers Dis 14: 1-16.

Evidente VG, Adler CH, Sabbagh MN, Connor DJ, Hentz JG, Caviness JN, Sue LI, Beach TG. 2011. Neuropathological findings of PSP in the elderly without clinical PSP: Possible incidental PSP? Parkinsonism Relat Disord 17: 365-371.

Feany MB, Dickson DW. 1995. Widespread cytoskeletal pathology characterizes corticobasal degeneration. Am J Pathol 146: 1388-1396.

Frigerio R, Fujishiro H, Ahn TB, Josephs KA, Maraganore DM, DelleDonne A, Parisi JE, Klos KJ, Boeve BF, Dickson DW, et al. 2011. Incidental Lewy body disease: Do some cases represent a preclinical stage of dementia with Lewy bodies? Neurobiol Aging 32: 857-863.

Fujishiro H, Uchikado H, Arai T, Hasegawa M, Akiyama H, Yokota O, Tsuchiya K, Togo T, Iseki E, Hirayasu Y. 2009. Accumulation of phosphorylated TDP-43 in brains of patients with argyrophilic grain disease. Acta Neuropathol 117: $151-158$.

Fukumoto H, Asami-Odaka A, Suzuki N, Iwatsubo T. 1996. Association of $A \beta 340$-positive senile plaques with microglial cells in the brains of patients with Alzheimer's disease and in non-demented aged individuals. Neurodegeneration 5: 13-17.

Galvin JE, Lee VM, Baba M, Mann DM, Dickson DW, Yamaguchi H, Schmidt ML, Iwatsubo T, Trojanowski JQ. 1997. Monoclonal antibodies to purified cortical Lewy bodies recognize the mid-size neurofilament subunit. Ann Neurol 42: 595-603.

Ghasemi M, Brown R. 2016. Genetics of amyotrophic lateral sclerosis. Cold Spring Harb Perspect Med doi: 10.1101/ cshperspect.a024125.

Ghetti B, Dlouhy SR, Giaccone G, Bugiani O, Frangione B, Farlow MR, Tagliavini F. 1995. Gerstmann-Sträussler-
Scheinker disease and the Indiana kindred. Brain Pathol 5: 61-75.

Gibb WR, Lees AJ. 1988. The relevance of the Lewy body to the pathogenesis of idiopathic Parkinson's disease. J Neurol Neurosurg Psychiatry 51: 745-752.

Gibb WR, Luthert PJ, Marsden CD. 1989. Corticobasal degeneration. Brain 112: 1171-1192.

Gijselinck I, Cruts M, Van Broeckhoven C. 2016. The genetics of C9orf72 expansions. Cold Spring Harb Perspect Med doi: $10.1101 /$ cshperspect.a026757.

Gilman S, Wenning GK, Low PA, Brooks DJ, Mathias CJ, Trojanowski JQ, Wood NW, Colosimo C, Durr A, Fowler CJ, et al. 2008. Second consensus statement on the diagnosis of multiple system atrophy. Neurology 71: 670-676.

Goedert M, Klug A, Crowther RA. 2006. Tau protein, the paired helical filament and Alzheimer's disease. $J \mathrm{Alz}$ heimers Dis 9: 195-207.

Goldfarb LG, Brown P, McCombie WR, Goldgaber D, Swergold GD, Wills PR, Cervenakova L, Baron H, Gibbs CJ Jr, Gajdusek DC. 1991. Transmissible familial CreutzfeldtJakob disease associated with five, seven, and eight extra octapeptide coding repeats in the PRNP gene. Proc Natl Acad Sci 88: 10926-10930.

Grundke-Iqbal I, Iqbal K, Quinlan M, Tung YC, Zaidi MS, Wisniewski HM. 1986. Microtubule-associated protein tau. A component of Alzheimer paired helical filaments. J Biol Chem 261: 6084-6089.

Halliday G, Hely M, Reid W, Morris J. 2008. The progression of pathology in longitudinally followed patients with Parkinson's disease. Acta Neuropathol 115: 409-415.

Halliday GM, Holton JL, Revesz T, Dickson DW. 2011. Neuropathology underlying clinical variability in patients with synucleinopathies. Acta Neuropathol 122: 187-204.

Hardy J, Duff K, Hardy KG, Perez-Tur J, Hutton M. 1998. Genetic dissection of Alzheimer's disease and related dementias: amyloid and its relationship to tau. Nat Neurosci 1: $355-358$.

Hassan A, Whitwell JL, Boeve BF, Jack CR Jr, Parisi JE, Dickson DW, Josephs KA. 2010. Symmetric corticobasal degeneration (S-CBD). Parkinsonism Relat Disord 16: 208 214.

* Hinz FI, Geschwind DH. 2016. Molecular genetics of neurodegerative dementia. Cold Spring Harb Perspect Biol doi: 10.1101/cshperspect.a023705.

Hof PR, Bouras C, Buee L, Delacourte A, Perl DP, Morrison JH. 1992. Differential distribution of neurofibrillary tangles in the cerebral cortex of dementia pugilistica and Alzheimer's disease cases. Acta Neuropathol 85: 23-30.

Holton JL, Ghiso J, Lashley T, Rostagno A, Guerin CJ, Gibb G, Houlden H, Ayling H, Martinian L, Anderton BH, et al. 2001. Regional distribution of amyloid-Bri deposition and its association with neurofibrillary degeneration in familial British dementia. Am J Pathol 158: 515-526.

Hsiao KK, Cass C, Schellenberg GD, Bird T, Devine-Gage E, Wisniewski H, Prusiner SB. 1991. A prion protein variant in a family with the telencephalic form of GerstmannStraussler-Scheinker syndrome. Neurology 41: 681-684.

Hu WT, Josephs KA, Knopman DS, Boeve BF, Dickson DW, Petersen RC, Parisi JE. 2008. Temporal lobar predominance of TDP-43 neuronal cytoplasmic inclusions in Alzheimer disease. Acta Neuropathol 116: 215-220. 
B.N. Dugger and D.W. Dickson

Hughes AJ, Daniel SE, Kilford L, Lees AJ. 1992. Accuracy of clinical diagnosis of idiopathic Parkinson's disease: A clinico-pathological study of 100 cases. J Neurol Neurosurg Psychiatry 55: 181-184.

Hutton M, Lendon CL, Rizzu P, Baker M, Froelich S, Houlden H, Pickering-Brown S, Chakraverty S, Isaacs A, Grover A, et al. 1998. Association of missense and $5^{\prime}$ splice-site mutations in tau with the inherited dementia FTDP-17. Nature 393: 702-705.

Hyman BT, Trojanowski JQ. 1997. Consensus recommendations for the postmortem diagnosis of Alzheimer disease from the National Institute on Aging and the Reagan Institute Working Group on diagnostic criteria for the neuropathological assessment of Alzheimer disease. Neuropathol Exp Neurol 56: 1095-1097.

Ikeda K, Akiyama H, Haga C, Kondo H, Arima K, Oda T. 1994. Argyrophilic thread-like structure in corticobasal degeneration and supranuclear palsy. Neurosci Lett 174: 157-159.

Ince PG, Highley JR, Kirby J, Wharton SB, Takahashi H, Strong MJ, Shaw PJ. 2011. Molecular pathology and genetic advances in amyotrophic lateral sclerosis: An emerging molecular pathway and the significance of glial pathology. Acta Neuropathol 122: 657-671.

Irizarry MC, Growdon W, Gomez-Isla T, Newell K, George JM, Clayton DF, Hyman BT. 1998. Nigral and cortical Lewy bodies and dystrophic nigral neurites in Parkinson's disease and cortical Lewy body disease contain $\alpha$-synuclein immunoreactivity. J Neuropathol Exp Neurol 57: 334-337.

Ishizawa T, Mattila P, Davies P, Wang D, Dickson DW. 2003. Colocalization of tau and $\alpha$-synuclein epitopes in Lewy bodies. J Neuropathol Exp Neurol 62: 389-397.

Janocko NJ, Brodersen KA, Soto-Ortolaza AI, Ross OA, Liesinger AM, Duara R, Graff-Radford NR, Dickson DW, Murray ME. 2012. Neuropathologically defined subtypes of Alzheimer's disease differ significantly from neurofibrillary tangle-predominant dementia. Acta Neuropathol 124: 681-692.

Josephs KA, Dickson DW. 2003. Diagnostic accuracy of progressive supranuclear palsy in the Society for Progressive Supranuclear Palsy brain bank. Mov Disord 18: 1018 1026.

Josephs KA, Tsuboi Y, Cookson N, Watt H, Dickson DW. 2004. Apolipoprotein E epsilon 4 is a determinant for Alzheimer-type pathologic features in tauopathies, syn ucleinopathies, and frontotemporal degeneration. Arch Neurol 61: 1579-1584.

Josephs KA, Lin WL, Ahmed Z, Stroh DA, Graff-Radford NR, Dickson DW. 2008a. Frontotemporal lobar degeneration with ubiquitin-positive, but TDP-43-negative inclusions. Acta Neuropathol 116: 159-167.

Josephs KA, Whitwell JL, Ahmed Z, Shiung MM, Weigand SD, Knopman DS, Boeve BF, Parisi JE, Petersen RC, Dickson DW, et al. 2008b. $\beta$-Amyloid burden is not associated with rates of brain atrophy. Ann Neurol 63: 204-212.

Josephs KA, Whitwell JL, Parisi JE, Knopman DS, Boeve BF, Geda YE, Jack CR Jr, Petersen RC, Dickson DW. 2008c. Argyrophilic grains: A distinct disease or an additive pathology? Neurobiol Aging 29: 566-573.

Josephs KA, Murray ME, Whitwell JL, Parisi JE, Petrucelli L, Jack CR, Petersen RC, Dickson DW. 2014. Staging TDP-
43 pathology in Alzheimer's disease. Acta Neuropathol 127: $441-450$.

Kang J, Lemaire HG, Unterbeck A, Salbaum JM, Masters CL, Grzeschik KH, Multhaup G, Beyreuther K, Muller-Hill B. 1987. The precursor of Alzheimer's disease amyloid A4 protein resembles a cell-surface receptor. Nature 325: 733-736.

Kertesz A, Hudson L, Mackenzie IR, Munoz DG. 1994. The pathology and nosology of primary progressive aphasia. Neurology 44: 2065-2072.

* Kolb HC, Andrés JI. 2016. Tau positron emission tomography imaging. Cold Spring Harb Perspect Biol doi: 10.1101/cshperspect.a023721.

Kosaka K, Yoshimura M, Ikeda K, Budka H. 1984. Diffuse type of Lewy body disease: Progressive dementia with abundant cortical Lewy bodies and senile changes of varying degree-A new disease? Clin Neuropathol 3: $185-192$.

Kouri N, Whitwell JL, Josephs KA, Rademakers R, Dickson DW. 2011. Corticobasal degeneration: A pathologically distinct 4R tauopathy. Nat Rev Neurol 7: 263-272.

Kovacs GG. 2015. Invited review: Neuropathology of tauopathies: Principles and practice. Neuropathol Appl Neurobiol 41: 3-23.

Kovacs GG, Ferrer I, Grinberg LT, Alafuzoff I, Attems J, Budka H, Cairns NJ, Crary JF, Duyckaerts C, Ghetti B, et al. 2016. Aging-related tau astrogliopathy (ARTAG): Harmonized evaluation strategy. Acta Neuropathol 131: 87-102.

Kuo YM, Kokjohn TA, Beach TG, Sue LI, Brune D, Lopez JC, Kalback WM, Abramowski D, Sturchler-Pierrat C, Staufenbiel M, et al. 2001. Comparative analysis of amyloid- $\beta$ chemical structure and amyloid plaque morphology of transgenic mouse and Alzheimer's disease brains. J Biol Chem 276: 12991-12998.

Kuusisto E, Parkkinen L, Alafuzoff I. 2003. Morphogenesis of Lewy bodies: Dissimilar incorporation of $\alpha$-synuclein, ubiquitin, and p62. J Neuropathol Exp Neurol 62: $1241-$ 1253.

Lantos PL. 1998. The definition of multiple system atrophy: A review of recent developments. J Neuropathol Exp Neurol 57: 1099-1111.

Lee VM, Goedert M, Trojanowski JQ. 2001. Neurodegenerative tauopathies. Annu Rev Neurosci 24: 1121-1159.

Leverenz JB, Umar I, Wang Q, Montine TJ, McMillan PJ, Tsuang DW, Jin J, Pan C, Shin J, Zhu D, et al. 2007. Proteomic identification of novel proteins in cortical lewy bodies. Brain Pathol 17: 139-145.

Lomen-Hoerth C, Anderson T, Miller B. 2002. The overlap of amyotrophic lateral sclerosis and frontotemporal dementia. Neurology 59: 1077-1079.

Mackenzie IRA, Neumann M. 2016. Fused in sarcoma neuropathology in neurodegenerative disease. Cold Spring Harb Perspect Med doi: 10.1101/cshperspect.a024299.

Mackenzie IR, Baborie A, Pickering-Brown S, Du Plessis D, Jaros E, Perry RH, Neary D, Snowden JS, Mann DM. 2006. Heterogeneity of ubiquitin pathology in frontotemporal lobar degeneration: Classification and relation to clinical phenotype. Acta Neuropathol 112: 539-549.

Mackenzie IR, Neumann M, Bigio EH, Cairns NJ, Alafuzoff I, Kril J, Kovacs GG, Ghetti B, Halliday G, Holm IE, et al. 
2010. Nomenclature and nosology for neuropathologic subtypes of frontotemporal lobar degeneration: An update. Acta Neuropathol 119: 1-4.

Mackenzie IR, Neumann M, Baborie A, Sampathu DM, Du Plessis D, Jaros E, Perry RH, Trojanowski JQ, Mann DM, Lee VM. 2011. A harmonized classification system for FTLD-TDP pathology. Acta Neuropathol 122: 111-113.

Mandelkow EM, Mandelkow E. 2012. Biochemistry and cell biology of tau protein in neurofibrillary degeneration. Cold Spring Harb Perspect Med 2: a006247.

Martin L, Latypova X, Terro F. 2011. Post-translational modifications of tau protein: implications for Alzheimer's disease. Neurochem Int 58: 458-471.

Masters CL, Simms G, Weinman NA, Multhaup G, McDonald BL, Beyreuther K. 1985. Amyloid plaque core protein in Alzheimer disease and Down syndrome. Proc Natl Acad Sci 82: 4245-4249.

McKee AC, Cantu RC, Nowinski CJ, Hedley-Whyte ET, Gavett BE, Budson AE, Santini VE, Lee HS, Kubilus CA, Stern RA. 2009. Chronic traumatic encephalopathy in athletes: Progressive tauopathy after repetitive head injury. $\mathrm{J} \mathrm{Neu-}$ ropathol Exp Neurol 68: 709-735.

McKee AC, Stern RA, Nowinski CJ, Stein TD, Alvarez VE, Daneshvar DH, Lee HS, Wojtowicz SM, Hall G, Baugh CM, et al. 2013. The spectrum of disease in chronic traumatic encephalopathy. Brain 136: 43-64.

McKee AC, Cairns NJ, Dickson DW, Folkerth RD, Dirk Keene C, Litvan I, Perl DP, Stein TD, Vonsattel JP, Stewart W, et al. 2015. The first NINDS/NIBIB consensus meeting to define neuropathological criteria for the diagnosis of chronic traumatic encephalopathy. Acta Neuropathol 131: 75-86.

McKeith IG, Dickson DW, Lowe J, Emre M, O’Brien JT, Feldman H, Cummings J, Duda JE, Lippa C, Perry EK, et al. 2005. Diagnosis and management of dementia with Lewy bodies: Third report of the DLB Consortium. Neurology 65: 1863-1872.

Milenkovic I, Kovacs GG. 2013. Incidental corticobasal degeneration in a 76-year-old woman. Clin Neuropathol 32: 69-72.

Mirra SS, Heyman A, McKeel D, Sumi SM, Crain BJ, Brownlee LM, Vogel FS, Hughes JP, van Belle G, Berg L. 1991 The Consortium to Establish a Registry for Alzheimer's Disease (CERAD). Part II: Standardization of the neuropathologic assessment of Alzheimer's disease. Neurology 41: 479-486.

Montenigro PH, Corp DT, Stein TD, Cantu RC, Stern RA. 2015. Chronic traumatic encephalopathy: Historical origins and current perspective. Annu Rev Clin Psychol 11: 309-330.

Montine TJ, Phelps CH, Beach TG, Bigio EH, Cairns NJ, Dickson DW, Duyckaerts C, Frosch MP, Masliah E, Mirra SS, et al. 2012. National Institute on Aging-Alzheimer's Association guidelines for the neuropathologic assessment of Alzheimer's disease: A practical approach. Acta Neuropathol 123: 1-11.

Morishima M, Ihara Y. 1994. Posttranslational modifications of tau in paired helical filaments. Dementia 5 282-288.

Murray ME, Graff-Radford NR, Ross OA, Petersen RC, Duara R, Dickson DW. 2011. Neuropathologically defined subtypes of Alzheimer's disease with distinct clin- ical characteristics: A retrospective study. Lancet Neurol 10: $785-796$.

Neumann M, Sampathu DM, Kwong LK, Truax AC, Micsenyi MC, Chou TT, Bruce J, Schuck T, Grossman M, Clark CM, et al. 2006. Ubiquitinated TDP-43 in frontotemporal lobar degeneration and amyotrophic lateral sclerosis. Science 314: 130-133.

Neumann M, Mackenzie IR, Cairns NJ, Boyer PJ, Markesbery WR, Smith CD, Taylor JP, Kretzschmar HA, Kimonis VE, Forman MS. 2007. TDP-43 in the ubiquitin pathology of frontotemporal dementia with VCP gene mutations. J Neuropathol Exp Neurol 66: 152-157.

Petersen RC, Parisi JE, Dickson DW, Johnson KA, Knopman DS, Boeve BF, Jicha GA, Ivnik RJ, Smith GE, Tangalos EG, et al. 2006. Neuropathologic features of amnestic mild cognitive impairment. Arch Neurol 63: 665-672.

Polymeropoulos MH, Lavedan C, Leroy E, Ide SE, Dehejia A, Dutra A, Pike B, Root H, Rubenstein J, Boyer R, et al. 1997. Mutation in the $\alpha$-synuclein gene identified in families with Parkinson's disease. Science 276: $2045-$ 2047.

Prusiner SB. 1982. Novel proteinaceous infectious particles cause scrapie. Science 216: 136-144.

Prusiner SB. 1998. Prions. Proc Natl Acad Sci 95: 1336313383.

Prusiner SB, Woerman AL, Rampersaud R, Watts JC, Berry DB, Patel S, Oehler A, Lowe JK, Kravitz SN, Geschwind DH, et al. 2015. Evidence for $\alpha$-synuclein prions causing multiple system atrophy in humans with signs of Parkinson's disease. Proc Natl Acad Sci 112: E5308-E5317.

Ratti A, Buratti E. 2016. Physiological Functions and Pathobiology of TDP-43 and FUS/TLS proteins. J Neurochem 138: $95-111$.

Rebeiz JJ, Kolodny EH, Richardson EP Jr. 1968. Corticodentatonigral degeneration with neuronal achromasia. Arch Neurol 18: 20-33.

Renton AE, Majounie E, Waite A, Símon-Sánchez J, Rollinson S, Gibbs JR, Schymick JC, Laaksovirta H, van Swieten JC, Myllykangas L, et al. 2011. A hexanucleotide repeat expansion in C9ORF72 is the cause of chromosome 9p21-linked ALS-FTD. Neuron 72: 257-268.

Roberts GW. 1988. Immunocytochemistry of neurofibrillary tangles in dementia pugilistica and Alzheimer's disease: Evidence for common genesis. Lancet 2: $1456-$ 1458.

Sampathu DM, Neumann M, Kwong LK, Chou TT, Micsenyi M, Truax A, Bruce J, Grossman M, Trojanowski JQ, Lee VM. 2006. Pathological heterogeneity of frontotemporal lobar degeneration with ubiquitin-positive inclusions delineated by ubiquitin immunohistochemistry and novel monoclonal antibodies. Am J Pathol 169: $1343-1352$.

Schmidt ML, Zhukareva V, Newell KL, Lee VM, Trojanowski JQ. 2001. Tau isoform profile and phosphorylation state in dementia pugilistica recapitulate Alzheimer's disease. Acta Neuropathol 101: 518-524.

Schmitt FA, Davis DG, Wekstein DR, Smith CD, Ashford JW, Markesbery WR. 2000. "Preclinical" AD revisited: Neuropathology of cognitively normal older adults. Neurology 55: 370-376. 
B.N. Dugger and D.W. Dickson

Schultz C, Ghebremedhin E, Del Tredici K, Rub U, Braak H. 2004. High prevalence of thorn-shaped astrocytes in the aged human medial temporal lobe. Neurobiol Aging 25: 397-405.

* Seeley WW. 2016. Mapping neurodegenerative disease onset and progression. Cold Spring Harb Perspect Biol doi: 10.1101/cshperspect.a023622.

Selikhova M, Williams DR, Kempster PA, Holton JL, Revesz T, Lees AJ. 2009. A clinico-pathological study of subtypes in Parkinson's disease. Brain 132: 2947-2957.

Sherzai A, Edland SD, Masliah E, Hansen L, Pizzo DP, Corey-Bloom J. 2013. Spongiform change in dementia with Lewy bodies and Alzheimer disease. Alzheimer Dis Assoc Disord 27: 157-161.

Sparks DL, Danner FW, Davis DG, Hackney C, Landers T, Coyne CM. 1994. Neurochemical and histopathologic alterations characteristic of Pick's disease in a non-demented individual. J Neuropathol Exp Neurol 53: 37-42.

Spillantini MG, Goedert M. 2013. Tau pathology and neurodegeneration. Lancet Neurol 12: 609-622.

Spillantini MG, Schmidt ML, Lee VM, Trojanowski JQ, Jakes R, Goedert M. 1997. $\alpha$-Synuclein in Lewy bodies. Nature 388: 839-840.

Stern RA, Daneshvar DH, Baugh CM, Seichepine DR, Montenigro PH, Riley DO, Fritts NG, Stamm JM, Robbins CA, McHale L, et al. 2013. Clinical presentation of chronic traumatic encephalopathy. Neurology 81: 1122-1129.

Sudhof TC, Rizo J. 2011. Synaptic vesicle exocytosis. Cold Spring Harb Perspect Biol 3: a005637.

Tagliavini F, Giaccone G, Frangione B, Bugiani O. 1988. Preamyloid deposits in the cerebral cortex of patients with Alzheimer's disease and nondemented individuals. Neurosci Lett 93: 191-196.

TCW J, Goate AM. 2016. Genetics of $\beta$-amyloid precursor protein in Alzheimer's disease. Cold Spring Harb Perspect Med doi: 10.1101/cshperspect.a024539.

Thal DR, Rub U, Orantes M, Braak H. 2002. Phases of A $\beta$ deposition in the human brain and its relevance for the development of AD. Neurology 58: 1791-1800.

Thenganatt MA, Jankovic J. 2014. Parkinson disease subtypes. JAMA Neurol 71: 499-504.

Togo T, Cookson N, Dickson DW. 2002a. Argyrophilic grain disease: Neuropathology, frequency in a dementia brain bank and lack of relationship with apolipoprotein E. Brain Pathol 12: 45-52.

Togo T, Sahara N, Yen SH, Cookson N, Ishizawa T, Hutton M, de Silva R, Lees A, Dickson DW. 2002b. Argyrophilic grain disease is a sporadic 4-repeat tauopathy. J Neuropathol Exp Neurol 61: 547-556.

Toledo JB, Gopal P, Raible K, Irwin DJ, Brettschneider J, Sedor S, Waits K, Boluda S, Grossman M, Van Deerlin VM, et al. 2016. Pathological $\alpha$-synuclein distribution in subjects with coincident Alzheimer's and Lewy body pathology. Acta Neuropathol 131: 393-409.

Tolnay M, Clavaguera F. 2004. Argyrophilic grain disease: A late-onset dementia with distinctive features among tauopathies. Neuropathology 24: 269-283.
Tolnay M, Probst A. 1998. Ballooned neurons expressing $\alpha \mathrm{B}$-crystallin as a constant feature of the amygdala in argyrophilic grain disease. Neurosci Lett 246: 165-168.

Uchihara T, Tsuchiya K, Nakamura A, Akiyama H. 2005. Silver staining profiles distinguish Pick bodies from neurofibrillary tangles of Alzheimer type: Comparison between Gallyas and Campbell-Switzer methods. Acta Neuropathol 109: 483-489.

Uchikado H, DelleDonne A, Ahmed Z, Dickson DW. 2006a. Lewy bodies in progressive supranuclear palsy represent an independent disease process. J Neuropathol Exp Neurol 65: $387-395$.

Uchikado H, Lin WL, DeLucia MW, Dickson DW. 2006b. Alzheimer disease with amygdala Lewy bodies: A distinct form of $\alpha$-synucleinopathy. J Neuropathol Exp Neurol 65: 685-697.

Ueda K, Fukushima H, Masliah E, Xia Y, Iwai A, Yoshimoto M, Otero DA, Kondo J, Ihara Y, Saitoh T. 1993. Molecular cloning of cDNA encoding an unrecognized component of amyloid in Alzheimer disease. Proc Natl Acad Sci 90: $11282-11286$.

Vidal R, Frangione B, Rostagno A, Mead S, Revesz T, Plant G, Ghiso J. 1999. A stop-codon mutation in the BRI gene associated with familial British dementia. Nature 399: 776-781.

Vidal R, Revesz T, Rostagno A, Kim E, Holton JL, Bek T, Bojsen-Moller M, Braendgaard H, Plant G, Ghiso J, et al. 2000. A decamer duplication in the $3^{\prime}$ region of the BRI gene originates an amyloid peptide that is associated with dementia in a Danish kindred. Proc Natl Acad Sci 97: $4920-4925$.

Watts JC, Giles K, Oehler A, Middleton L, Dexter DT, Gentleman SM, DeArmond SJ, Prusiner SB. 2013. Transmission of multiple system atrophy prions to transgenic mice. Proc Natl Acad Sci 110: 19555-19560.

Weihl CC, Temiz P, Miller SE, Watts G, Smith C, Forman M, Hanson PI, Kimonis V, Pestronk A. 2008. TDP-43 accumulation in inclusion body myopathy muscle suggests a common pathogenic mechanism with frontotemporal dementia. J Neurol Neurosurg Psychiatry 79: 1186-1189.

Westermark P, Benson MD, Buxbaum JN, Cohen AS, Frangione B, Ikeda S, Masters CL, Merlini G, Saraiva MJ, Sipe JD. 2005. Amyloid: Toward terminology clarification. Report from the Nomenclature Committee of the International Society of Amyloidosis. Amyloid 12: 1-4.

Whitwell JL, Josephs KA, Murray ME, Kantarci K, Przybelski SA, Weigand SD, Vemuri P, Senjem ML, Parisi JE, Knopman DS, et al. 2008. MRI correlates of neurofibrillary tangle pathology at autopsy: Avoxel-based morphometry study. Neurology 71: 743-749.

Williams DR, Lees AJ. 2009. Progressive supranuclear palsy: Clinicopathological concepts and diagnostic challenges. Lancet Neurol 8: 270-279.

Woerman AL, Aoyagi A, Patel S, Kazmi SA, Lobach I, Grinberg LT, McKee AC, Seeley WW, Olson SH, Prusiner SB. 2016. Tau prions from Alzheimer's disease and chronic traumatic encephalopathy patients propagate in cultured cells. Proc Natl Acad Sci doi: 10.1073/pnas.1616344113. 


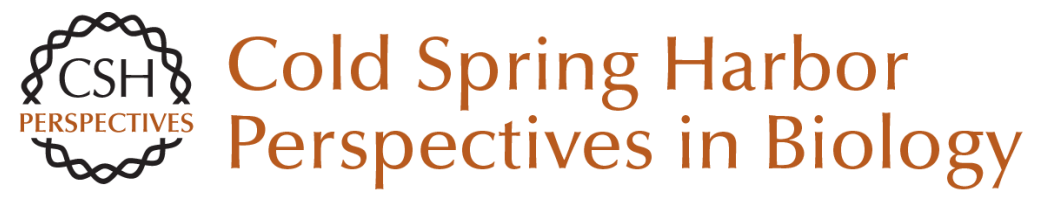

\section{Pathology of Neurodegenerative Diseases}

Brittany N. Dugger and Dennis W. Dickson

Cold Spring Harb Perspect Biol 2017; doi: 10.1101/cshperspect.a028035 originally published online January 6, 2017

\section{Subject Collection Prion Biology}

Genetic PrP Prion Diseases

Mee-Ohk Kim, Leonel T. Takada, Katherine Wong, et al.

Neurodegenerative Disease Transmission and Transgenesis in Mice Brittany N. Dugger, Daniel P. Perl and George A. Carlson

Toward the Atomic Structure of PrPSc Jose A. Rodriguez, Lin Jiang and David S. Eisenberg

Bioassays and Inactivation of Prions Kurt Giles, Amanda L. Woerman, David B. Berry, et al.

Functional Prions in the Brain Joseph B. Rayman and Eric R. Kandel

The Amyloid Phenomenon and Its Links with Human Disease Christopher M. Dobson

Tau Positron Emission Tomography Imaging Hartmuth C. Kolb and José Ignacio Andrés

Prion-Like Polymerization in Immunity and Inflammation

Xin Cai, Hui Xu and Zhijian J. Chen
Clinical Neurology and Epidemiology of the Major Neurodegenerative Diseases Michael G. Erkkinen, Mee-Ohk Kim and Michael D. Geschwind

Prion Properties of SOD1 in Amyotrophic Lateral Sclerosis and Potential Therapy Caroline Sibilla and Anne Bertolotti

Mapping Neurodegenerative Disease Onset and Progression William W. Seeley

Erratum: Functional Prions in the Brain Joseph B. Rayman and Eric R. Kandel

Pathology of Neurodegenerative Diseases Brittany N. Dugger and Dennis W. Dickson

TIA-1 Is a Functional Prion-Like Protein Joseph B. Rayman and Eric R. Kandel

Molecular Genetics of Neurodegenerative Dementias

Flora I. Hinz and Daniel H. Geschwind

Cross- $\beta$ Polymerization of Low Complexity

Sequence Domains

Masato Kato and Steven L. McKnight

For additional articles in this collection, see http://cshperspectives.cshlp.org/cgi/collection/

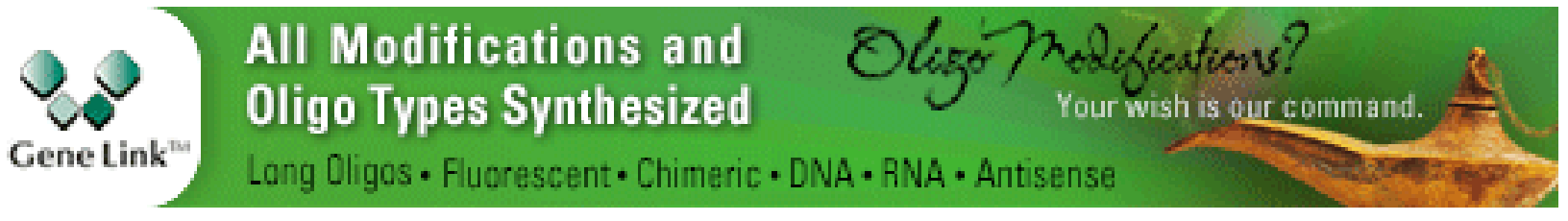

Copyright @ 2017 Cold Spring Harbor Laboratory Press; all rights reserved 